\title{
The Mount Perkins block, northwestern Arizona: An exposed cross section of an evolving, preextensional to synextensional magmatic system
}

\author{
James E. Faulds, ${ }^{1}$ Daniel L. Feuerbach, ${ }^{1}$ Mark K. Reagan, ${ }^{1}$ Rodney V. Metcalf, ${ }^{2}$ \\ Phil Gans, ${ }^{3}$ and J. D. Walker ${ }^{4}$
}

\begin{abstract}
The steeply tilted Mount Perkins block, northwestern Arizona, exposes a cross section of a magmatic system that evolved through the onset of regional extension. New ${ }^{40} \mathrm{Ar} /{ }^{39} \mathrm{Ar}$ ages of variably tilted $\left(0-90^{\circ}\right)$ volcanic strata bracket extension between 15.7 and 11.3 Ma. Preextensional intrusive activity included emplacement of a composite Miocene laccolith and stock, trachydacite dome complex, and east striking rhyolite dikes. Related volcanic activity produced an $\sim 18-16 \mathrm{Ma}$ stratovolcano, cored by trachydacite domes and flanked by trachydacite-trachyandesite flows, and $\sim 16$ Ma thyolite flows. Similar compositions indicate a genetic link between the stratovolcano and granodioritic phase of the laccolith. Magmatic activity synchronous with early regional extension (15.7-14.5 Ma) generated a thick, felsic volcanic sequence, a swarm of northerly striking subvertical rhyolite dikes, and rhyolite domes. Field relations and compositions indicate that the dike swarm and felsic volcanic sequence are cogenetic. Modes of magma emplacement changed during the onset of extension from subhorizontal sheets, east striking dikes, and stocks to northerly striking, subvertical dike swarms, as the regional stress field shifted from nearly isotropic to decidedly anisotropic with an east-west trending, horizontal least principal stress.

Preextensional trachydacitic and preextensional to synextensional rhyolitic magmas were part of an evolving system, which involved the ponding of mantle-derived basaltic magmas and ensuing crustal melting and assimilation at progressively shallower levels. Major extension halted this system by generating abundant pathways to the surface (fractures), which flushed out preexisting crustal melts and hybrid magmas. Remaining silicic melts were quenched by rapid, upper crustal cooling induced by tectonic denudation. These processes facilitated eruption of mafic magmas. Accordingly, silicic magmatism at Mount Perkins ended abruptly during peak extension $\sim 14.5 \mathrm{Ma}$ and gave way to mafic magmatism, which continued until extension ceased.
\end{abstract}

\section{Introduction}

The relations between magmatism and the dynamic and kinematic evolution of extensional terranes have been the subject of significant controversy. Many workers have proposed relationships between magmatism and extension in which (1) the emplacement of large volumes of magma at depth triggers extension at shallow crustal levels [e.g., Anderson, 1971; deVoogd et al., 1988; Gans et al., 1989; Meyer and Foland, 1991; Lister and Baldwin, 1993] or (2) the geometry of major normal faults, particularly detachment faults, controls the distribution and type of magmatism [e.g., Wernicke, 1985; Bosworth, 1987]. Others, however, have noted diachroneities in the timing of magmatism and extension within extended terranes [Bartley et al., 1988; Best and Christiansen, 1991; Taylor et al., 1989; Taylor and Bartley, 1992; Axen et al., 1993]. For example, some highly

\footnotetext{
${ }^{1}$ Department of Geology, University of Iowa, Iowa City.

${ }^{2}$ Department of Geoscience, University of Nevada, Las Vegas.

${ }^{3}$ Department of Geological Sciences, University of California, Santa Barbara.

${ }^{4}$ Department of Geology, University of Kansas, Lawrence.

Copyright 1995 by the American Geophysical Union.

Paper number 95JB01375.

0148-0227/95/95JB-01375\$05.00
}

extended regions are essentially amagmatic (e.g., southern Nevada in the Basin and Range province; [Eaton, 1982]), whereas some areas of intense volcanism within extensional settings (e.g., Mogollon-Datil volcanic field, New Mexico; [Elston, 1989]) have experienced little mechanical extension (i.e., faulting and tilting). One approach to elucidating the interplay between magmatism and extension is to examine an individual magmatic system that evolved during the onset or termination of extension.

Locating volcanic centers in extended terranes can be difficult, however, especially in the more highly extended regions. For example, sources for much of the widespread and voluminous Tertiary volcanism in the Basin and Range province have not been located [Lipman, 1984]. Moreover, most of the well-documented centers occur in mildly extended regions [Best and Christiansen, 1991], where tilts of fault blocks are generally less than $30^{\circ}$. Although much can be gleaned from volcanic centers in the mildly extended areas, the exposed structural levels in such regions are generally limited to the upper few kilometers of crust, which precludes comprehensive analysis of magmatic plumbing systems and emplacement mechanisms.

The difficulty in identifying volcanic centers, especially in highly extended regions, is a function of structural dismemberment by normal and strike-slip faults [e.g., Anderson, 1973], tilting, and erosion. Large-magnitude 
tilting may be the most effective agent for obscuring volcanic edifices. Tilting induces burial of the downthrown portions of fault blocks and erosion of the upthrown parts and thus greatly reduces the "exposure probability" of volcanic edifices. In some cases, however, tilting can reveal cross sections of magmatic systems from plutonic roots, through hypabyssal dike swarms, to surficial volcanic complexes [e.g., Proffett, 1977; Gans and Miller, 1983; Asmerom et al., 1990; Holm and Wernicke, 1990; John, 1995]. Studies of such systems can elucidate the interplay between magmatism and extension by permitting analysis of the emplacement mechanisms of intrusions, structural controls on volcanic centers, and petrogenesis of magmas.

The steeply tilted Mount Perkins block, northwestern Arizona, affords a cross-sectional view of the upper several kilometers of a magmatic system that was active before, during, and after the onset of major extension. We first describe the field relations and geochronological and geochemical evidence that indicate exposure of a tilted magmatic system and genetic ties between different structural levels of the system. The evolution of the system is then discussed within the context of regional extension.

\section{Geologic Setting}

\section{Northern Colorado River Extensional Corridor}

The Mount Perkins block lies within the central Black Mountains in the northern part of the Colorado River extensional corridor (Figure 1), a 70 - to $100-\mathrm{km}$-wide region of moderately to severely extended crust situated between the relatively unextended Colorado Plateau on the east and Spring Range-Old Woman Mountains region on the west [Howard and John, 1987; Faulds et al., 1990]. The extensional corridor terminates northward at the left-lateral Lake Mead fault system and right-lateral Las Vegas Valley shear zone. Thick sections (generally $>3 \mathrm{~km}$ ) of Miocene volcanic and sedimentary strata rest directly on Proterozoic and late Cretaceous metamorphic and plutonic rock within the extensional corridor [Longwell, 1963; Anderson, 1971; Frost and Martin, 1982; Sherrod and Nielson, 1993].

Calc-alkalic magmatism and extension swept northward across the northern part of the corridor in early to late Miocene time [Glazner and Bartley, 1984; Gans et al., 1989; Armstrong and Ward, 1991; Faulds et al., 1994a]. Most of the documented volcanic centers and plutons occur within three east-west trending magmatic belts [Smith and Faulds, 1994]. Magmatism began 1-2 m.y. before extension and generally continued through most of the extensional episode. Thus the corridor is dominated by highly fragmented, thick volcanic piles contained within complex arrays of tilted fault blocks. The average strike of tilted Miocene strata and slip data [Anderson, 1971, Angelier et al., 1985; J. E. Faulds, unpublished data, 1994] indicate an east-northeast $\left(\sim 075^{\circ}\right)$ to east-west extension direction within the Mount Perkins region.

Because magmatism preceded and continued during extension, the effects of regional extension on the evolution of individual magmatic systems can be evaluated. Appreciable tilting in many areas permits examination of both the plumbing systems and surficial volcanic edifices of individual magmatic centers. In the northernmost part of the corridor, several volcanic sequences have been correlated with cogenetic plutons on the basis of structural relations and geochemistry [Weber and Smith, 1987].

\section{Mount Perkins Block}

The Mount Perkins block is a steeply $\left(\sim 90^{\circ}\right)$ west tilted fault block that contains an apparently cogenetic suite of Miocene plutonic, hypabyssal, and volcanic rock [Faulds, 1993b] (Figures 1 and 2). The across-strike width of the steeply tilted exposures suggests that as much as $9 \mathrm{~km}$ of crust may be exposed on end within the Mount Perkins block. The block is bordered on the east by the gently $\left(5-30^{\circ}\right)$ eastnortheast dipping Mockingbird Mine fault and on the west by the moderately east dipping Mount Davis fault. The $30-\mathrm{km}$ long Mount Perkins block terminates abruptly northward at a major accommodation zone [Faulds et al., 1990] in conjunction with the along-strike termination of the east dipping normal fault system. The more diffuse, southern boundary of the block is related to a gradual southward decrease in displacement on the Mockingbird Mine fault (Figure 1).

The Mockingbird Mine fault originated as a steeply dipping normal fault and was rotated to a gentle dip by fault block tilting, as shown by steep tilts $\left(70-90^{\circ}\right)$ within both its hanging wall and footwall. Nucleation of the fault probably occurred shortly after the onset of extension and tilting, however, as $90^{\circ}$ of rotation would imply initiation as a steeply dipping reverse fault. Middle to late Tertiary reverse faults are very rare within the region. Asymmetric microstructures developed in breccia and gouge along the fault, such as $\mathbf{R}_{1}$ Riedel shears and rough facets [Angelier et al., 1985; Petit, 1987], indicate an east-northeast trending slip line (i.e., essentially dip-slip). Although piercing points have not been observed, offset volcanic strata and the orientation of the slip line suggest that the Mockingbird Mine fault accommodated a maximum of 5-6 km of slip in the vicinity of Mount Perkins.

In the Mount Perkins region, west tilting increases eastward across many of the major, east dipping normal faults. This suggests that fault block tilting was largely accommodated by displacement on concave upward, east dipping normal faults and dominolike tilting of intervening fault blocks [e.g., Proffett, 1977]. The Dupont Mountain fault on the east flank of the southern Eldorado Mountains accommodated the greatest amount of slip $(>10 \mathrm{~km})$ in the Mount Perkins region and probably facilitated considerable tilting of the Mount Perkins block. The Dupont Mountain fault may link southward with major detachment faults [Faulds et al., 1992] and eastward with a major subhorizontal discontinuity imaged at 5-6 km depth on seismic reflection profiles from Detrital Valley directly east of Mount Perkins (J. Faulds, unpublished data, 1995). The discontinuity probably accommodated much of the tilting of the Mount Perkins block. However, the amount of slip on the discontinuity has not been constrained.

\section{Timing of Extension and Magmatism}

As part of a regional investigation of the timing of magmatism and extension in the northern Colorado River extensional corridor, we have conducted a detailed ${ }^{40} \mathrm{Ar} /{ }^{39} \mathrm{Ar}$ study of magmatic activity in the Mount Perkins block and adjacent areas. Here we report 10 new high-precision ages of 


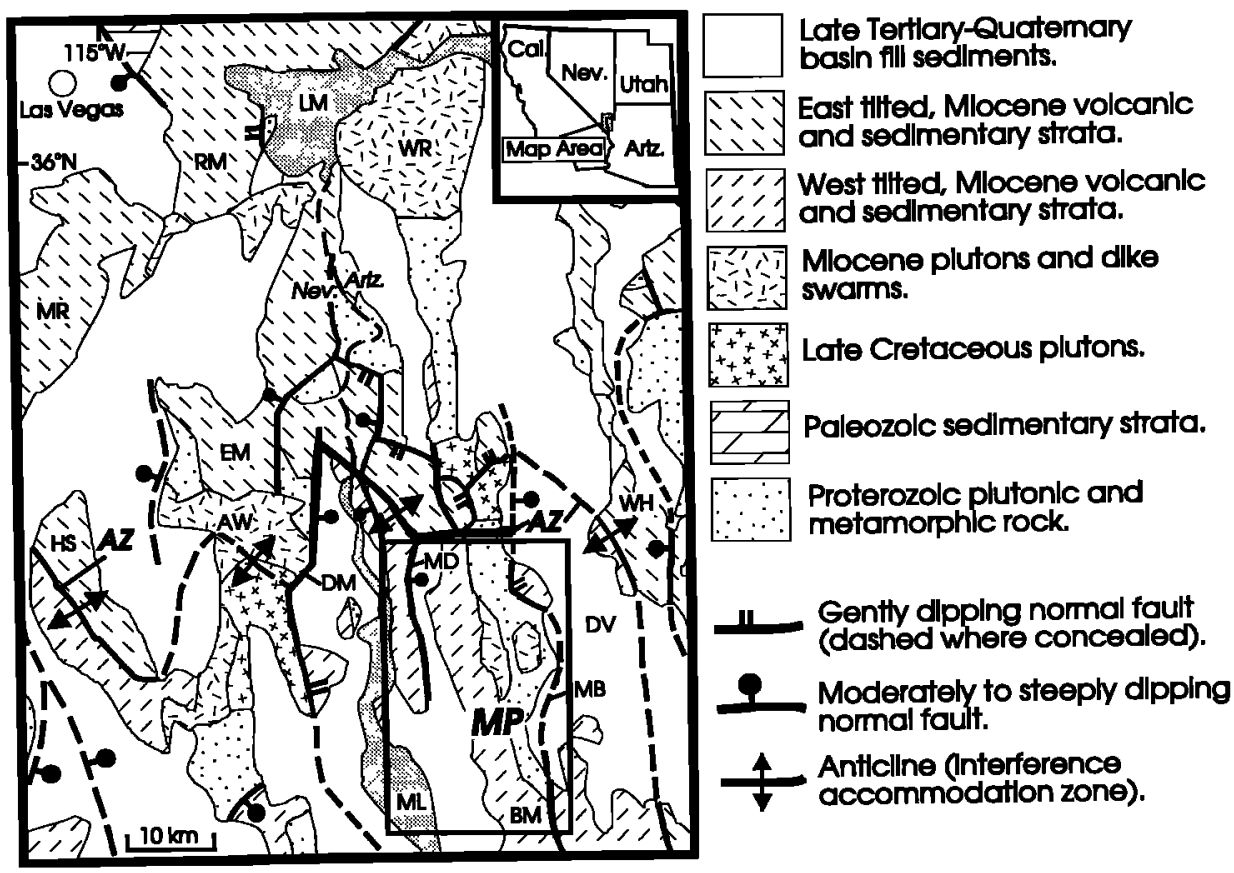

Figure 1. Generalized geologic map of the northern Colorado River extensional corridor [from Faulds, 1993a, also unpublished mapping and reconnaissance, 1994; Anderson, 1971, 1977, 1978]. Blocked out area refers to region shown in Figure 2. AZ, accommodation zone (separates east and west tilted domains); AW, Aztec Wash pluton; BM, Black Mountains; DM, Dupont Mountain fault; DV, Detrital Valley; EM, Eldorado Mountains; HS, Highland Spring Range; LM, Lake Mead; MB, Mockingbird Mine fault; MD, Mount Davis fault; ML, Lake Mohave; MP, Mount Perkins; MR, McCullough Range; RM, River Mountains; WH, White Hills; WR, Wilson Ridge pluton.

volcanic and plutonic rocks that constrain the timing and duration of volcanic activity, establish links between volcanic and intrusive activity, and tightly bracket the timing and rates of tilting associated with regional extension (Table 1 and Figure 3). Analytical techniques are described in the appendix.

The ${ }^{40} \mathrm{Ar} /{ }^{39} \mathrm{Ar}$ data demonstrate that volcanism within the Mount Perkins region began at $\sim 20 \mathrm{Ma}$ and continued without significant interruption until $\sim 11 \mathrm{Ma}$ (Table 1 and Figure 3 ). Major intrusions were emplaced from at least 16 to $\sim 14.5 \mathrm{Ma}$.

Extension within the region is tightly bracketed between 15.7 and $11.3 \mathrm{Ma}$ by ${ }^{40} \mathrm{Ar} /{ }^{39} \mathrm{Ar}$ ages of variably tilted volcanic strata within major growth-fault basins (Table 1 and Figure 3). Within the Mount Perkins block, west tilting of the lower part of the Miocene section locally exceeds $90^{\circ}$. Tilts fan upward to as little as $30^{\circ}$ within a major growth-fault basin in the western part of the block (Figures $2 b$ and 3 ). Directly west and east of the Mount Perkins block, tilts decrease upsection from $90^{\circ}$ to $0^{\circ}$. The youngest of the most steeply tilted units consistently yields ages of 15.7-15.8 Ma, whereas capping flat-lying units range from 11.3 to $11.5 \mathrm{Ma}$ (Table 1). In the Mount Perkins region, peak extension (i.e., highest rates of tilting) occurred between 15.2 and 14.3 Ma when tilting rates ranged from $50^{\circ}$ to $80^{\circ} / \mathrm{Ma}$ (Figure 3 ).

Volcanic and plutonic rocks at Mount Perkins are divided into preextensional (15.7-20 Ma) and synextensional (11.3$15.7 \mathrm{Ma}$ ) groups on the basis of well-exposed crosscutting relations and high-precision ${ }^{40} \mathrm{Ar} /{ }^{39} \mathrm{Ar}$ geochronologic data on critical units. This subdivision helps to clarify the relations between intrusive and extrusive rocks and the interplay between extension and magmatism.

\section{Preextensional Magmatism}

Preextensional ( $15.7-20 \mathrm{Ma})$ magmatism was primarily intermediate in composition and produced rock units exposed in the eastern and central parts of the Mount Perkins block (Table 2). The structurally lower, eastern part of the block contains the Miocene Mount Perkins pluton that was emplaced in Proterozoic orthogneiss. In the central and northern parts of the block, the foliation within the gneiss generally dips moderately southwest. Normal drag along the Mockingbird Mine fault has warped this foliation into gentle eastward dips along the easternmost margin of the block (Figure 2). South of the pluton, east striking, steeply dipping foliations dominate the gneiss. Large granitoid dikes with relatively low aspect ratios (length/width ratio $\leq 10.0$ ) constitute the bulk of the Mount Perkins pluton. Most of these dikes, as well as the eastern and western margins of the pluton, dip steeply eastward and thus crosscut the foliations in the gneiss. The pluton consists of three distinct phases: (1) an older gabbro that at least locally includes some diorite, (2) quartz diorite to hornblende granodiorite of intermediate age, and (3) younger biotite granodiorite and granite [Metcalf et al., 1993]. Phases 2 and 3 contain mafic enclaves.

The Mount Perkins pluton was originally emplaced as a subhorizontal tabular mass but was subsequently tilted significantly to the west. Paleomagnetic data indicate a minimum of $50^{\circ}$ of west tilting of the pluton [Faulds et al., 1992]. Moreover, an ${ }^{40} \mathrm{Ar} /{ }^{39} \mathrm{Ar}$ age on biotite of $15.96 \pm 0.06$ $\mathrm{Ma}$ from the younger granodiorite phase of the pluton (Table 1) suggests that the pluton was emplaced and cooled below the closure temperature of biotite $\left(-350-373^{\circ} \mathrm{C}\right)$ [Berger and 


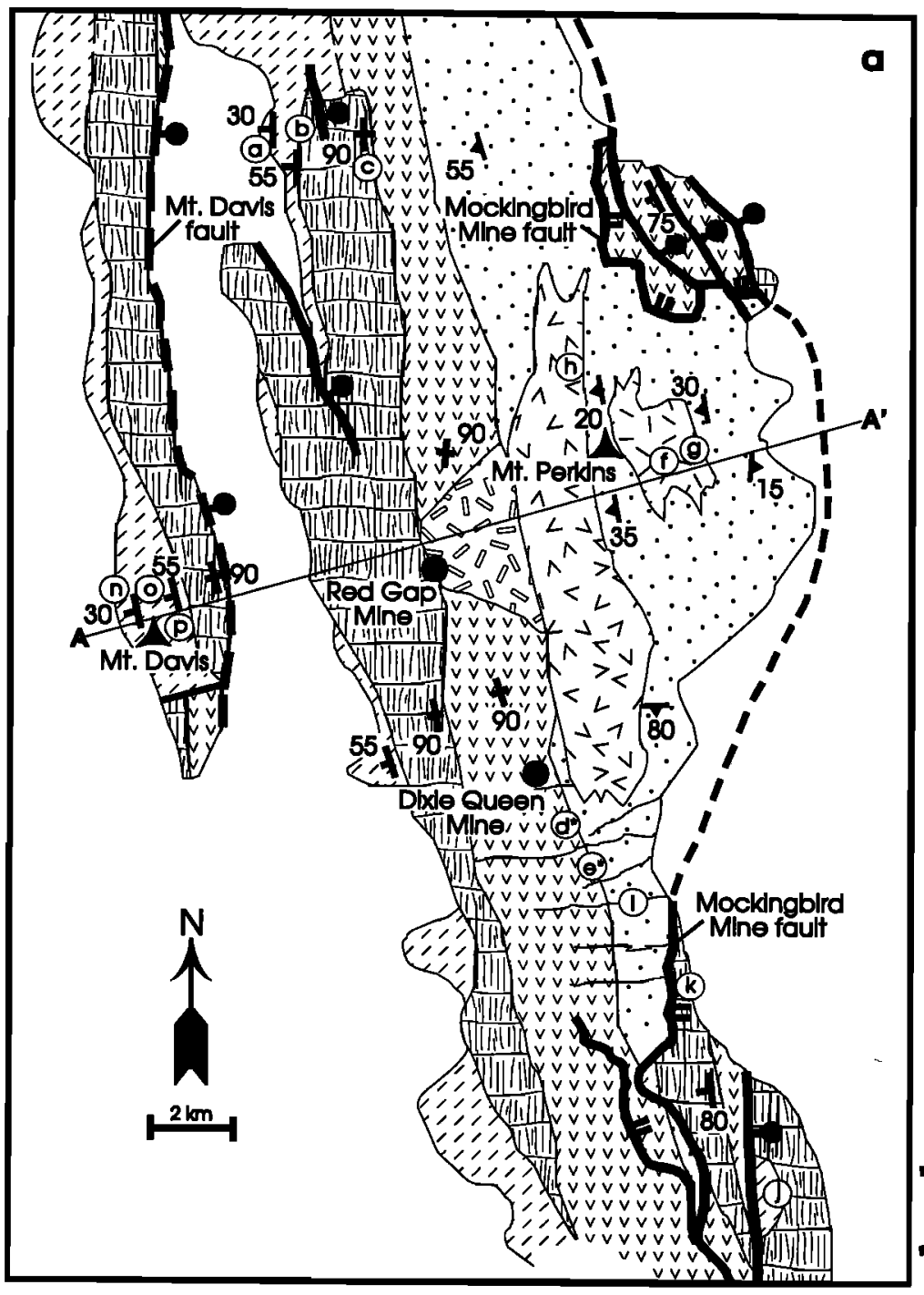

\section{EXPLANATION}

Quatemary-tate Mlocene basin fill sediments.

Mt. Dovls Volcanlos and Upper Member 1117 of Patsy Mine Volcanlcs; malnly 14.3-15.3 1, ,, Ma basalt flows; Includes 15.2 Ma Tuff of Bridge Sping.

आIIII) Red Gap Mine volcanlcs: 14.5-15.8 Ma rhyollte flows and tuffs.

$<M$ Mt. Perkins dlke swarm: 14.5-15.7 Ma inyollte dlke swarm.

\section{7-16.0 Ma ihyollte dlkes.}

Trachydaclte domes of the Dixle

\&ueen Mlne volconlcs.

Dixle Queen Mlne volcanlcs: 15.8-18.5

vvvy Ma trachydaclte and trachyandeslte

$\because \vee v y$ flows. Also Includes 18.5 Ma Peach Springs Tuff, 19-20 Ma basalt flows, and basal arkosic conglomerate.

17 Mt. Perkns pluton, 16.0 Ma granodlortte and granite; Includes older dlortte and gabbro phases.

$\therefore$ Early Proterozolc orthognelss.

Sample location for geochronology.

4 Strike and dip of layering.

4 Strike and dlp of follation.

1 Gently dlpplng normal fault (dashed where concealed).

$\{$ Moderately to steeply dlpplng normal foult (dashed where concealed).

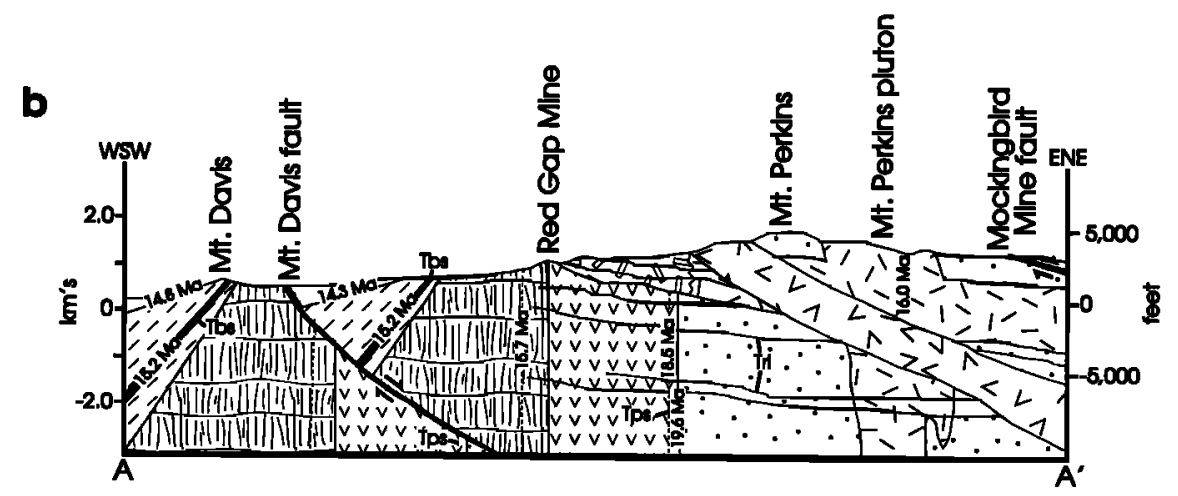

Figure 2. (a) Generalized geologic map of the Mount Perkins block. Because of the steep tilting, the map essentially represents a downplunge view of tilted volcanoes. Circled letters represent sample locations for geochronologic data shown in Figure 3 and Table 1. (b) Generalized cross section (no vertical exaggeration) of the Mount Perkins block. Thicknesses of stratigraphic units are slightly exaggerated, as numerous minor faults have been omitted for clarity. Tbs, 15.2 Ma Tuff of Bridge Spring; Tps, 18.5 Ma Peach Springs Tuff; Tri, rhyolite dikes. 
Table 1. Geochronologic Data

\begin{tabular}{|c|c|c|c|c|c|c|c|}
\hline Sample & Latitude $\mathrm{N}$ & Longitude W & $\begin{array}{l}\text { Magnitude } \\
\text { of West Tilt }\end{array}$ & Rock Type & Material Dated & $\begin{array}{c}\text { Apparent Age, } \\
\text { Ma }\end{array}$ & Source \\
\hline \multicolumn{8}{|c|}{ Mount Perkins Block } \\
\hline $\begin{array}{l}\text { a (JF92-27) } \\
\text { b (JF92-26) } \\
\text { c (JF92-25) } \\
d^{*}(J F 91-41) \\
\text { e*(JF92-32) } \\
\text { f (JF91-61) } \\
\text { f (JF92-242) } \\
\text { f (JF92-242) } \\
\text { g (JF92-244) } \\
\text { h (JF813) } \\
\text { i (Ti-1) }\end{array}$ & $\begin{array}{l}35^{\circ} 39^{\prime} 09^{\prime \prime} \\
35^{\circ} 39^{\prime} 14^{\prime \prime} \\
35^{\circ} 39^{\prime} 25^{\prime \prime} \\
35^{\circ} 46^{\prime} 36^{\prime \prime} \\
35^{\circ} 44^{\prime} 45^{\prime \prime} \\
35^{\circ} 35^{\prime} 08^{\prime \prime} \\
35^{\circ} 34^{\prime} 55^{\prime \prime} \\
35^{\circ} 34^{\prime} 55^{\prime \prime} \\
35^{\circ} 35^{\prime} 33^{\prime \prime} \\
35^{\circ} 35^{\prime} 00^{\prime \prime} \\
35^{\circ} 29^{\prime} 59^{\prime \prime}\end{array}$ & $\begin{array}{l}114^{\circ} 35^{\prime} 48^{\prime \prime} \\
114^{\circ} 35^{\prime} 23^{\prime \prime} \\
114^{\circ} 35^{\prime} 04^{\prime \prime} \\
114^{0} 36^{\prime} 01^{\prime \prime} \\
114^{\circ} 33^{\prime} 43^{\prime \prime} \\
114^{\circ} 28^{\prime} 35^{\prime \prime} \\
114^{\circ} 29^{\prime} 28^{\prime \prime} \\
114^{0} 29^{\prime} 28^{\prime \prime} \\
114^{\circ} 28^{\prime} 16^{\prime \prime} \\
114^{\circ} 31^{\prime} 17^{\prime \prime} \\
114^{\circ} 30^{\prime} 25^{\prime \prime}\end{array}$ & $\begin{array}{l}30^{\circ} \\
55^{\circ} \\
90^{\circ} \\
90^{\circ} \\
90^{\circ} \\
90^{\circ \dagger} \\
90^{\circ \dagger} \\
90^{\circ \dagger} \\
90^{\circ \dagger} \\
45^{\circ \dagger} \\
90^{\circ \dagger}\end{array}$ & $\begin{array}{c}\text { basalt flow } \\
\text { basalt flow } \\
\text { rhyolite tuff } \\
\text { Peach Springs Tuff } \\
\text { basalt flow } \\
\text { granodiorite } \\
\text { granodiorite } \\
\text { granodiorite } \\
\text { gabbro } \\
\text { rhyolite dike } \\
\text { rhyolite dike }\end{array}$ & $\begin{array}{c}\text { Whole Rock } \\
\text { Whole Rock } \\
\text { Biotite } \\
\text { Sanidine } \\
\text { Whole Rock } \\
\text { Biotite } \\
\text { Apatite } \\
\text { Zircon } \\
\text { Apatite } \\
\text { K-spar } \\
\text { Biotite }\end{array}$ & $\begin{array}{c}14.27 \pm 0.12 \\
14.5 \pm 0.1 \\
15.74 \pm 0.10 \\
18.46 \pm 0.05 \\
19.9 \pm 0.5 \\
15.96 \pm 0.06 \\
14.60 \pm 3.0 \\
16.10 \pm 1.0 \\
14.10 \pm 4.0 \\
14.50 \pm 0.30 \\
15.7 \pm 0.4\end{array}$ & $\begin{array}{l}\text { A } \\
\text { A } \\
\text { A } \\
\text { A } \\
\text { A } \\
\text { A } \\
\text { B } \\
\text { B } \\
\text { B } \\
\text { C } \\
\text { D }\end{array}$ \\
\hline \multicolumn{8}{|c|}{ Directly East of Mount Perkins Block } \\
\hline $\begin{array}{l}\mathrm{j} \text { (TPV-AND) } \\
\mathrm{k}(87-9)\end{array}$ & $\begin{array}{l}35^{\circ} 24 ' 21^{\prime \prime} \\
35^{\circ} 27^{\prime} 11^{\prime \prime}\end{array}$ & $\begin{array}{l}114^{\circ} 26^{\prime} 21^{\prime \prime} \\
114^{\circ} 29^{\prime} 10^{\prime \prime}\end{array}$ & $\begin{array}{c}0^{\circ} \\
80^{\circ}\end{array}$ & $\begin{array}{c}\text { basaltic andesite flow } \\
\text { tuff }\end{array}$ & $\begin{array}{c}\text { Whole Rock } \\
\text { Biotite }\end{array}$ & $\begin{array}{l}11.4 \pm 0.4 \\
15.7 \pm 0.3\end{array}$ & $\begin{array}{l}\mathrm{D} \\
\mathrm{D}\end{array}$ \\
\hline \multicolumn{8}{|c|}{ Directly West of Mount Perkins Block } \\
\hline $\begin{array}{l}1 \text { (JF92-44) } \\
\text { m (JF92-45) } \\
\text { n (JF92-34) } \\
\text { o (JF92-35) } \\
\text { p (JF92-37) }\end{array}$ & $\begin{array}{l}35^{\circ} 34^{\prime} 45^{\prime \prime} \\
35^{\circ} 33^{\prime} 05^{\prime \prime} \\
35^{\circ} 33^{\prime} 08^{\prime \prime} \\
35^{\circ} 32^{\prime} 52^{\prime \prime} \\
35^{\circ} 32^{\prime} 52^{\prime \prime}\end{array}$ & $\begin{array}{l}114^{\circ} 45^{\prime} 40^{\prime \prime} \\
114^{\circ} 45^{\prime} 00^{\prime \prime} \\
114^{\circ} 38^{\prime} 23^{\prime \prime} \\
114^{\circ} 38^{\prime} 02^{\prime \prime} \\
114^{\circ} 37^{\prime} 54^{\prime \prime}\end{array}$ & $\begin{array}{c}0^{\circ} \\
15^{\circ} \\
30^{\circ} \\
40^{\circ} \\
60^{\circ}\end{array}$ & $\begin{array}{c}\text { basalt flow } \\
\text { basalt flow } \\
\text { basalt flow } \\
\text { rhyolite tuff } \\
\text { tuff of Bridge Spring }\end{array}$ & $\begin{array}{c}\text { Whole Rock } \\
\text { Whole Rock } \\
\text { Whole Rock } \\
\text { Sanidine } \\
\text { Sanidine }\end{array}$ & $\begin{array}{l}11.35 \pm 0.10 \\
12.78 \pm 0.02 \\
14.79 \pm 0.03 \\
14.97 \pm 0.02 \\
15.21 \pm 0.02\end{array}$ & $\begin{array}{l}\text { A } \\
\text { A } \\
\text { A } \\
\text { A } \\
\text { A }\end{array}$ \\
\hline
\end{tabular}

$\mathrm{A},{ }^{40} \mathrm{Ar} /{ }^{39} \mathrm{Ar}$ dates from P. Gans, University of California, Santa Barbara; B, fission track ages from D. Foster, LaTrobe University; C, K/Ar date from Faulds et al. [1992]; D, K/Ar date from Conrad et al. [1990]. Errors quoted at $\pm 1 \sigma$. Analytical data for A are reported in Table $\mathrm{A} 1^{1}$. More detailed information for $\mathrm{B}$ and $\mathrm{C}$ can be obtained from J. Faulds upon request. Sample locations (except 1 and $\mathrm{m}$ ) are shown on Figure 2.

*Samples were not obtained from Mount Perkins block, but correlative units crop out near base of section in the Mount Perkins block.

${ }^{\dagger}$ Tilting inferred from paleomagnetic data and geologic relations [Faulds et al., 1992].

York, 1981] prior to the onset of extension at $15.7 \mathrm{Ma}$. Thus the pluton has probably been tilted $\sim 90^{\circ}$ to the west along with the bulk of the Mount Perkins block. The steeply dipping dikes that comprise the pluton were probably emplaced as subhorizontal sheets.

Reconstruction of the Mount Perkins block suggests that the central part of the Mount Perkins pluton was emplaced at a depth of approximately $5.5 \pm 1.0 \mathrm{~km}$. The reconstruction involves restoring several minor faults (not shown on Figure 2), untilting, and removal of younger intrusions. The "reconstructed" emplacement depth is compatible with Al-inhornblende geobarometry [Schmidt, 1992] for granodiorite phases of the pluton, which yield pressures of $2.1 \pm 0.6 \mathrm{kbars}$ indicating crystallization depths of $7.5 \pm 2.2 \mathrm{~km}$ [Metcalf et al., 1995].

A set of widely spaced, east to northeast striking, rhyolite dikes is also interpreted as part of the preextensional magmatic system. These steeply dipping, quartz-phenocrystbearing dikes cut Proterozoic gneisses and the preextensional lower part of the Miocene section in the Mount Perkins-Dixie Queen Mine area but do not cut the synextensional parts of the Miocene section. Biotite from one dike gave a $\mathrm{K} / \mathrm{Ar}$ age of $15.7 \pm 0.4 \mathrm{Ma}$ [Conrad et al., 1990]. The east to northeast strikes of the dikes and their absence in synextensional parts of the Miocene section suggest emplacement prior to the onset of major east-west extension.

In ascending order above an early Miocene ( $20 \mathrm{Ma})$ nonconformity, the preextensional, lower part of the Miocene section within the Mount Perkins block consists of (1) up to $30 \mathrm{~m}$ of arkosic conglomerate locally capped by thin $\sim 19-20$
Ma basaltic lava flows, (2) a thin (0-30 m) 18.46 Ma (Table 1) rhyolite tuff, which is probably correlative with the Peach Springs Tuff [cf. Nielson et al., 1990, Glazner et al., 1986]; (3) a 2-km-thick sequence of trachyandesite and trachydacite flows, which is here referred to as the Dixie Queen Mine volcanics; the lower trachyandesite flows interfinger with and are overlain by trachydacite flows and domes; and (4) the lowermost part of a 15.8-14.5 Ma felsic volcanic sequence, which includes quartz-phenocryst-bearing rhyolite flows, tuffs, surge deposits, and tuffaceous sedimentary rocks and is here referred to as the Red Gap Mine volcanics based on excellent exposures near the Red Gap Mine (Table 2 and Figure 2). The Dixie Queen and Red Gap Mine volcanics are temporally correlative with the Lower and Middle Members, respectively, of the Patsy Mine Volcanics of Anderson [1971]. However, the volcanic sequences within the Mt. Perkins block and Patsy Mine Volcanics were probably not derived from the same volcanic centers. The lower, preextensional part of the Red Gap Mine volcanics and the east to northeast striking set of rhyolite dikes have similar spatial distributions, compositions, and ages and may therefore be cogenetic. Although a slight angular unconformity $\left(10^{\circ}\right)$ locally separates the basal arkose and Peach Springs Tuff, dips are generally concordant within the lower part of the Miocene section and average $90^{\circ}$ (Figure 3). This suggests that the lower part of the Miocene section was deposited prior to any significant regional extension.

Several features indicate that the Dixie Queen Mine volcanics largely comprise a preextensional stratovolcano that has been tilted $90^{\circ}$ and is therefore exposed in cross section 


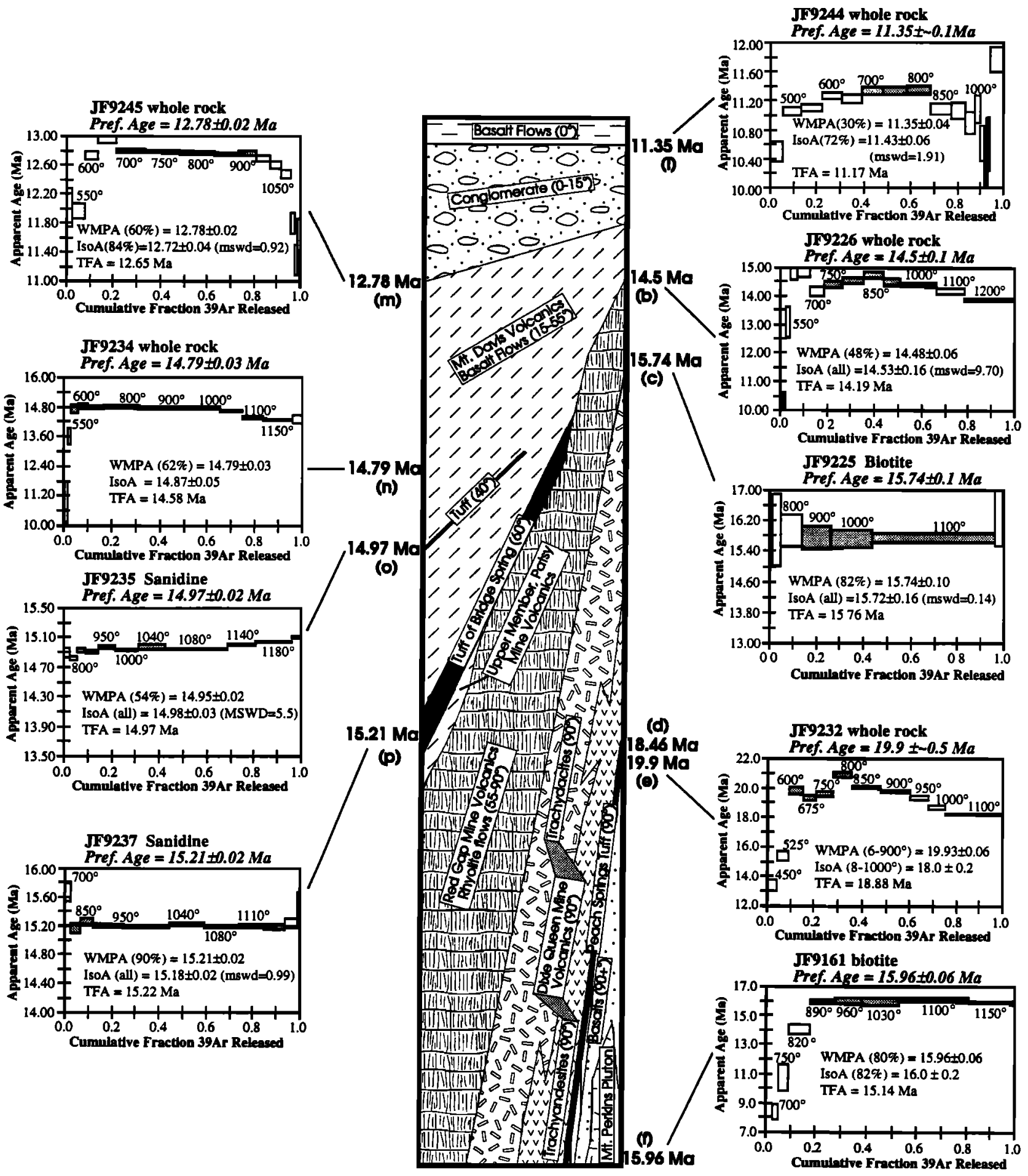

Figure 3. Composite stratigraphic column of the Mount Perkins region showing approximate tilts. The ${ }^{40} \mathrm{Ar} /{ }^{39} \mathrm{Ar}$ age spectra are shown for critical units. Letters in parentheses represent sample locations shown in Figure 2 and Table 1. Weighted mean plateau ages (WMPA) were calculated for shaded parts of the spectra. Temperatures are in ${ }^{\circ} \mathrm{C}$. TFA, total fusion age; IsoA, Issochron age. Data quality are assessed in the appendix. 
Table 2. Stratigraphic Column, Mount Perkins Block

\begin{tabular}{|c|c|}
\hline Extrusive & Intrusive \\
\hline \multicolumn{2}{|c|}{ Synextensional $(15.7-11.3 \mathrm{Ma})$} \\
\hline \multicolumn{2}{|l|}{$\begin{array}{l}\text { Basalt flows, isolated }(\sim 11.3 \mathrm{Ma}) \\
\text { Basin-filling fanglomerates } \\
\text { Mount Davis Volcanics (15.2-12.8 Ma) } \\
\text { Basalt and basaltic andesite flows } \\
\text { Tuff of Bridge Spring (15.2 Ma) } \\
\text { Upper Member, Patsy Mine Volcanics } \\
\text { Basaltic andesite flows (15.3 Ma) }\end{array}$} \\
\hline $\begin{array}{l}\text { Bulk of Red Gap Mine volcanics } \\
\text { Rhyolite flows and domes } \\
\text { Nonwelded rhyolite tuffs } \\
\text { Quartz phenocrysts } \\
\text { 15.7-14.5 Ma }\end{array}$ & $\begin{array}{l}\text { Mount Perkins rhyolite dike swarm } \\
\text { NNW striking, east dipping } \\
\text { Emplaced at steep dips } \\
\text { Quartz phenocrysts } \\
\text { 14.5-15.7 Ma }\end{array}$ \\
\hline \multicolumn{2}{|c|}{ Preextensional $(\sim 20-15.7 \mathrm{Ma})$} \\
\hline $\begin{array}{l}\text { Lowermost Red Gap Mine volcanics } \\
\text { Rhyolite flows and tuffs } \\
\text { Quartz phenocrysts } \\
\sim 16.0-15.7 \mathrm{Ma} \\
\text { Dixie Queen Mine volcanics } \\
\text { Upper trachydacite flows and domes } \\
\text { Lower trachyandesite flows } \\
\text { Peach Springs Tuff (18.5 Ma) } \\
\text { Basalt flows (19-20 Ma) } \\
\text { Arkosic conglomerate } \\
\sim 20 \text { Ma nonconformity }\end{array}$ & $\begin{array}{l}\text { Rhyolite dikes ( } 15.7 \mathrm{Ma}) \\
\text { Quartz phenocrysts } \\
\text { ENE striking, steeply dipping } \\
\text { Mount Perkins pluton: Laccolith and stock } \\
15.96 \text { Ma granite-granodiorite } \\
\text { Older diorite-gabbro }\end{array}$ \\
\hline
\end{tabular}

Dashed lines denote unconformities; solid lines are conformable contacts.

(Figure 2). Just to the north of the Dixie Queen Mine, lava flows within the Dixie Queen Mine volcanics give way to a massive body of trachydacite that exceeds $2 \mathrm{~km}$ in thickness. The massive trachydacite cuts a 5-km-long segment of the early Miocene nonconformity and is thus interpreted as a tilted trachydacite dome complex. The trachydacite dome appears to merge eastward in the vicinity of the nonconformity with isolated exposures of altered diorite and granite, which are cut by younger dikes. The diorite and granite in this area are interpreted as the upper part of a tilted stock. Strikes of steeply tilted strata within the trachydacite and trachyandesite units swing from northwest to northnortheast from south to north around the trachydacite dome complex (Figure 2). These relations suggest that the trachydacite dome complex and trachydacite and trachyandesite flows correspond to the central core and flanks, respectively, of a stratovolcano that has been tilted $-90^{\circ}$. The discordance in the strike of strata north and south of the dacite dome complex probably reflects primary dips off the flanks of the stratovolcano (Figure 2). The central part of the inferred stratovolcano lies west-southwest of the Mount Perkins pluton and thus originally rested above the pluton.

\section{Synextensional Magmatism}

Within the Mount Perkins block, voluminous outpourings of felsic volcanic rock coincided with the onset of extension $-15.7 \mathrm{Ma}$ but gave way to widespread mafic volcanism essentially during peak extension 14.5-15.2 Ma (Figure 3 and Table 2). The western part of the Mount Perkins block incor- porates a large growth-fault basin within which the synextensional volcanic rocks accumulated. In ascending order, the section within the basin includes (1) the middle and upper parts of the Red Gap Mine volcanics, which consist of 300$1500+\mathrm{m}$ of quartz-phenocryst-bearing rhyolite flows, nonwelded tuffs, surge deposits, and tuffaceous sedimentary rocks bracketed between 15.8 and $15.2 \mathrm{Ma}$ in the Red Gap Mine area and 15.8 and $14.5 \mathrm{Ma}$ near the northem margin of the basin (Figure 2 and Table 1), (2) as much as $100 \mathrm{~m}$ of basaltic andesite lava flows that correlate with the Upper Member of the Patsy Mine Volcanics of Anderson [1971], (3) the 15.2 Ma Tuff of Bridge Spring [Anderson, 1971; Smith et al., 1993], which was probably erupted from a caldera in the northern Eldorado Mountains [Gans et al., 1994] and thus corresponds to an outflow sheet in the Mount Perkins area, (4) as much as $1 \mathrm{~km}$ of basalt and basaltic andesite flows, which correlate with the Mount Davis Volcanics of Anderson [1971] and range from 15.2 to 14.3 $\mathrm{Ma}$ in the Mount Perkins block and 15.2 to $12.8 \mathrm{Ma}$ just to the west and north of Mount Davis, and (5) middle to late Miocene basin-filling fanglomerates (Figures 2 and 3). The transition from felsic to mafic magmatism within the Mount Perkins block occurred rapidly, as demonstrated by conformable relations and relatively little interfingering between the Red Gap Mine and Mount Davis volcanic sequences (Figures $2 \mathrm{~b}$ and 3 ). Tilts within the Mount Perkins and nearby structural blocks fan from 90 to $55^{\circ}$ between the lower part of the Red Gap Mine volcanics and Tuff of Bridge Spring, 55 to $15^{\circ}$ in the Mount Davis Volcanics, and 15 to $0^{\circ}$ in the fanglomerates and isolated exposures of flat-lying, basaltic lava flows (Figure $2 \mathrm{~b}$ ). 
Synextensional rhyolitic magmatism also included emplacement of the Mount Perkins dike swarm, a massive 20$\mathrm{km}$-long, felsic dike swarm within the central part of the Mount Perkins block (Figure 2). The east dipping, northerly striking dike swarm invades the Proterozoic gneisses and lower part of the Miocene section. It is essentially a sheeted dike complex that ranges up to $1 \mathrm{~km}$ in thickness. Directly east of the Red Gap Mine area, nearly the entire west flank of Mount Perkins consists of felsic dikes. Individual dikes are characterized by widths of less than $10 \mathrm{~m}$ and high aspect ratios (length/width $>100$ ). Some dikes extend laterally for several kilometers. The thickest part of the dike swarm lies between the Mount Perkins pluton and dacite dome complex (Figure 2). The dikes are generally low to high silica rhyolites and contain quartz phenocrysts, but a few hornblende dacite dikes are also present. Some dikes contain inclusions of granodiorite that resemble the granodiorite and granite phases of the Mount Perkins pluton. Widely spaced northerly striking, east dipping rhyolite dikes that cut the pluton may be cogenetic with the larger dike swarm. Similar spatial distributions and compositions imply a genetic link between the synextensional northerly striking dike swarm and the preextensional set of east to northeast striking dikes.

A significant range in dip magnitudes, crosscutting relations, and paleomagnetic data indicate a synextensional origin for the Mount Perkins dike swarm. The dikes dip 0 to $45^{\circ}$ eastward and thus crosscut foliation in the Proterozoic gneisses. Many of the more gently dipping, older dikes are cut by moderately dipping, younger dikes. Paleomagnetic data suggest at least $45^{\circ}$ of west-tilting of the dike swarm [Faulds et al., 1992]. One moderately dipping dike yielded a $\mathrm{K} / \mathrm{Ar}$ age of $14.5 \pm 0.30 \mathrm{Ma}$ on $\mathrm{K}$-spar (Table 1). The dike swarm terminates upsection in the lower part of the 14.5-15.8 Ma Red Gap Mine volcanics and is thus roughly bracketed between 15.8 and 14.5 Ma. These relations suggest that most of the dikes were emplaced at approximately vertical orientations during extension and were progressively rotated to easterly dips by west tilting of the Mount Perkins block. The range in dip magnitudes is complementary to the fanning of tilts within the Red Gap Mine volcanics.

Field relations indicate a genetic tie between the Mount Perkins dike swarm and Red Gap Mine volcanics. For example, the rhyolite dike swarm terminates upward in the lower part of the Red Gap Mine volcanics. In addition, along-strike terminations of the dike swarm roughly coincide with appreciable thinning or pinch outs of the Red Gap Mine volcanics (Figure 2). Abundant and thick rhyolite flows further imply a nearby source for the felsic volcanic sequence in the Red Gap Mine area, which lies directly west of the thickest part of the Mount Perkins dike swarm. To the north and south, rhyolite flows give way to nonwelded tuffs and tuffaceous sedimentary rocks. The common quartz-bearing composition of the Mount Perkins dike swarm and rhyolite flows in the Red Gap Mine volcanics is also relatively distinct within the region, as other rhyolite sequences of similar age are generally free of quartz phenocrysts [e.g., Anderson, 1977, 1978 ].

The physical and temporal relations strongly suggest that the Mount Perkins block exposes an oblique cross section of a synextensional rhyolite dome complex. Prior to tilting, the Red Gap Mine volcanics rested directly above the Mount Perkins dike swarm. The rhyolite lava flows in the Red Gap Mine area were probably deposited proximal to the dome complex, whereas the predominant nonwelded tuffs to the north and south accumulated on distal aprons of the rhyolite domes. Rhyolite domes have not been observed in the Red Gap Mine area but are present in the hanging wall of the Mockingbird Mine fault (Figures 1 and 2), where massive bodies of rhyolite with vitrophyric rinds are surrounded by thick accumulations of interbedded nonwelded tuffs, surge deposits, and tuffaceous sedimentary rocks.

\section{Geochemistry}

The major element, trace element, and isotopic compositions of Miocene igneous rocks from the Mount Perkins block have been determined to investigate their petrogenesis [Feuerbach et al., 1994; Metcalf et al., 1995]. Here these compositions are used to evaluate the genetic relationship between volcanic and intrusive rocks within the Mount Perkins block and the association between the preextensional intermediate and preextensional to synextensional rhyolitic magmatism. Geochemical data of representative samples are shown in Table 3. Analytical methods are discussed in the appendix.

Much of the Dixie Queen Mine volcanics and some dike rocks have been altered to varying degrees by hydrothermal activity. The alteration most commonly involves sericitization of plagioclase and conversion of mafic constituents to Fe-oxides and sheet silicates. Minor sulfides are also locally developed. Samples analyzed from the Dixie Queen Mine volcanics contained no sulfides and only minor alteration of silicate minerals. The Red Gap Mine volcanics have experienced little or no alteration. Geochemical plots of all elements show coherent trends, suggesting little metasomatism and essentially primary compositions. Nonetheless, to avoid potential problems associated with alteration, relatively immobile rare earth and high field strength elements, such as $\mathrm{Hf}$ and $\mathrm{Ta}$, were employed to assess the proposed correlations whenever possible.

The lava flows and intrusive rocks within the Mount Perkins block can be divided into intermediate, felsic, and mafic groups on the basis of $\mathrm{SiO}_{2}$ compositions (Figure 4). The intermediate group includes the preextensional trachyandesite flows $\left(56.4 \% \mathrm{wt} \% \mathrm{SiO}_{2}\right)$ and trachydacite flows and domes (61.8-66.3 wt \% $\mathrm{SiO}_{2}$ ) of the 18.5-16 Ma Dixie Queen Mine volcanics and quartz diorite to hornblende granodiorite phase (55.8-67.6 wt \% $\mathrm{SiO}_{2}$ ) of the Mount Perkins pluton. The preextensional $15.96 \mathrm{Ma}$ biotite granodiorite to granite phase (70.1-74.2 wt \% $\mathrm{SiO}_{2}$ ) of the Mount Perkins pluton, 14.5-15.8 Ma preextensional to synextensional Red Gap Mine volcanics (72.0-77.4 wt \% $\mathrm{SiO}_{2}$ ), and synextensional Mount Perkins dike swarm (73.01-77.4 wt $\% \mathrm{SiO}_{2}$ ) constitute the felsic group. The mafic group incorporates the gabbro and mafic enclaves from the Mount Perkins pluton [Metcalf et al., $1995]$, an older (> $16 \mathrm{Ma}$ ) dioritic phase $\left(51.6 \mathrm{wt} \% \mathrm{SiO}_{2}\right)$ of the Mount Perkins pluton, 15.3 Ma synextensional basaltic andesite flows of the Upper Member of the Patsy Mine Volcanics, and 14.3-15.2 Ma basalt flows of the Mount Davis Volcanics. Sampling efforts for this study focused on the intermediate and felsic groups, because these compositions bracket the onset of major regional extension and make up the extrusive and intrusive parts of volcanic centers at Mount Perkins.

Striking similarities in the abundances and trends of rare earth and high field strength elements and $\mathrm{Nd}$ and $\mathrm{Sr}$ isotopic 


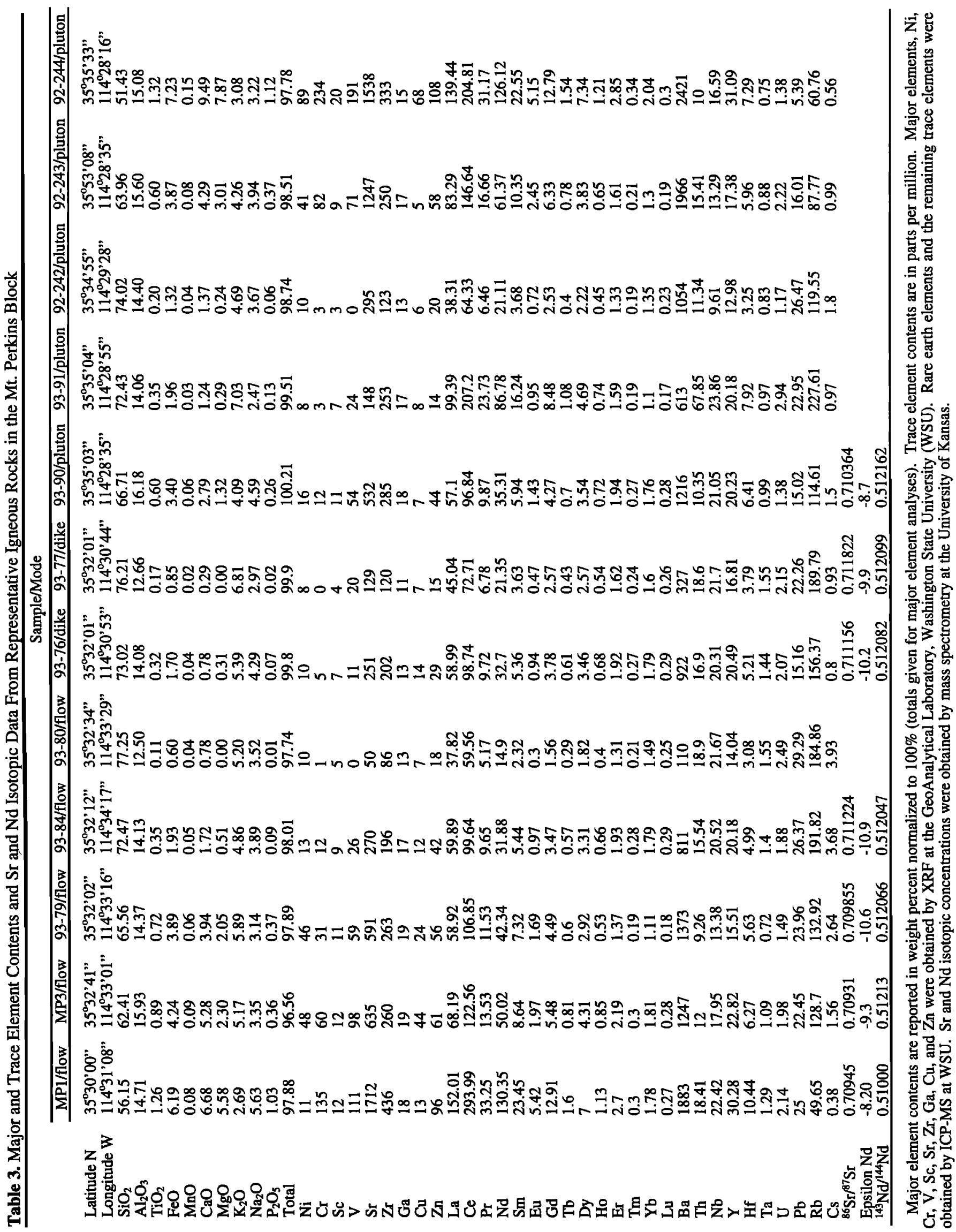




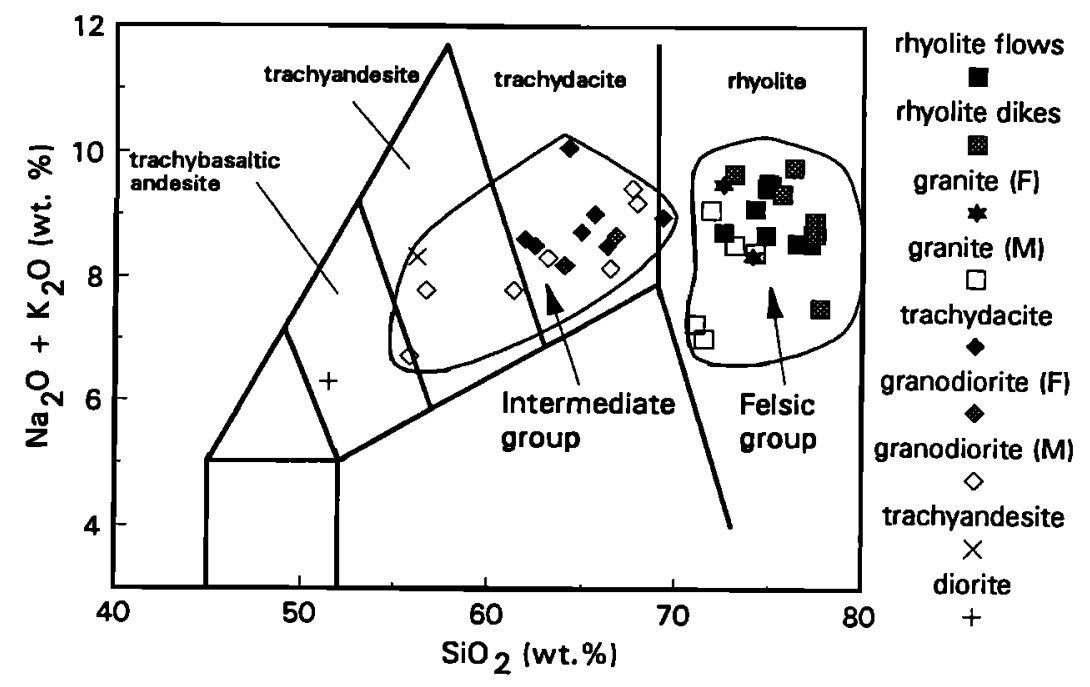

Figure 4. $\mathrm{Na}_{2} \mathrm{O}+\mathrm{K}_{2} \mathrm{O}$ versus $\mathrm{SiO}_{2}$ for volcanic and intrusive rocks associated with the Mount Perkins magmatic system. The classification scheme is from LeBas et al. [1986].

compositions suggest that plutonic and volcanic rocks within the intermediate and felsic groups are cogenetic. For example, relatively shallow rare earth element (REE) slopes, depleted middle REE, and negative Eu anomalies characterize the extrusive and intrusive rocks of the felsic group, including the rhyolite flows and dikes, as well as the granodioritegranite phase of the Mount Perkins pluton (Figure 5b). In addition, the rhyolite dikes and flows and granodiorite-granite phase of the Mount Perkins pluton have similar Hf/Ta ratios (2.0 to 4.1) and Ta concentrations (1.3 to $2.2 \mathrm{ppm}$ ) (Figure 6). Nearly identical $\mathrm{Sr}$ and $\mathrm{Nd}$ isotopic compositions (Figure 7) of the granodiorite-granite phase of the pluton [Metcalf et al., 1995], rhyolite dikes, and rhyolite flows further suggest that they are cogenetic. Within the intermediate group, both the quartz diorite to granodiorite phase [Metcalf et al., 1995] and trachydacites have moderate REE abundances, steep REE trends, and no Eu anomaly (Figure 5a). Though compositions of the plutonic rocks are more scattered than those of the trachydacite flows and domes, Hf/Ta ratios of the trachydacites and quartz diorite to granodiorite phase overlap (values range from 4 to 8; Figure 6a) and are consistently higher than that of the felsic group. The trachydacite flows and domes and higher silica $\left(>62 \% \mathrm{SiO}_{2}\right.$ ) granodiorite of the Mount Perkins pluton also have similar $\mathrm{Sr}$ and $\mathrm{Nd}$ isotopic compositions (Figure 7).

Limited data preclude a thorough analysis of potential correlations between extrusive and intrusive rocks of the mafic group, but do permit some speculations. The diorite and trachyandesite samples have similar REE abundances and patterns and trace element ratios (Figures 5a and 6), suggesting that the older diorite phase of the pluton and some of the $\sim 16-18.5 \mathrm{Ma}$ trachyandesite flows in the Dixie Queen Mine volcanics may be genetically related. However, the trace element compositions of the trachyandesite and older diorite phase of the pluton differ significantly from those of the mafic enclaves and older gabbro reported by Metcalf et al. [1995] (Figure 5a). Diverse mafic sources may account for these differences.

The geochemical data do not afford unequivocal evidence for correlating volcanic and plutonic units within the Mount
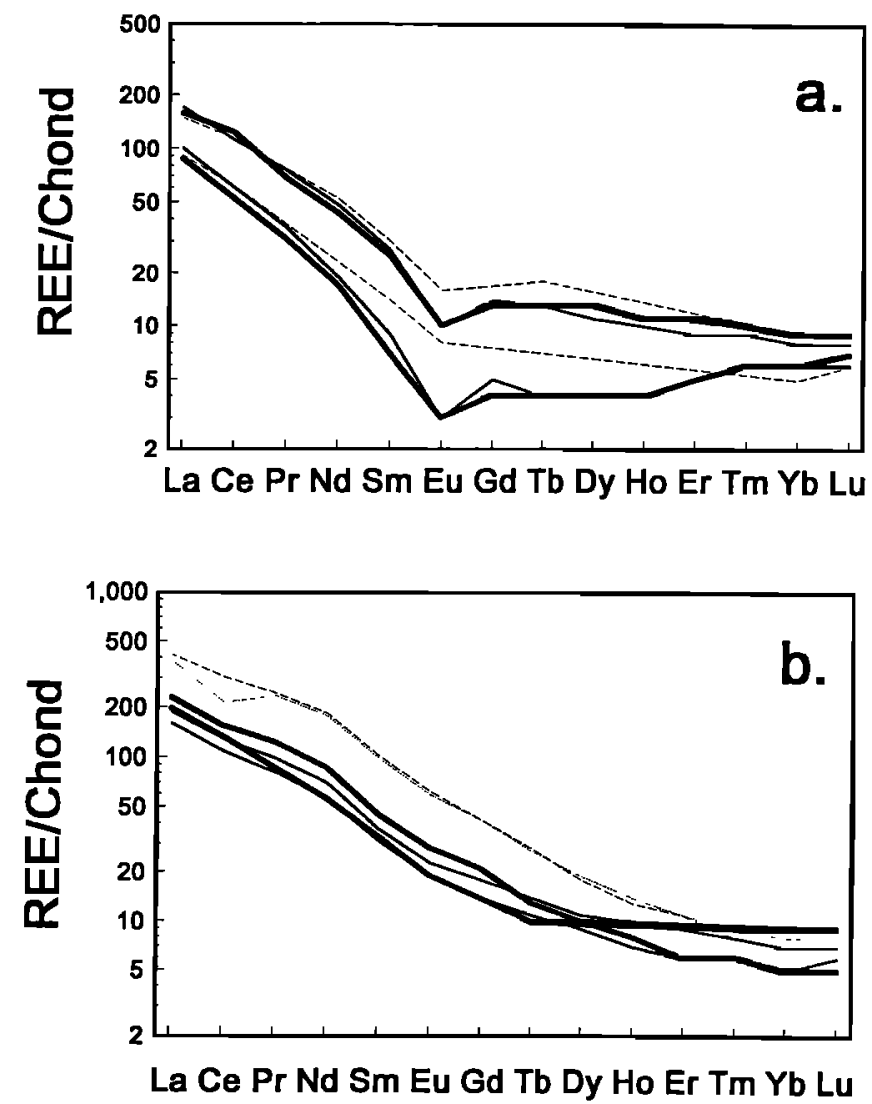

Figure 5. (a) REE/chondrite plot for the felsic magma group. Heavy solid lines are rhyolite dikes; medium solid lines are rhyolite flows; thin dashed lines are granites from the Mount Perkins pluton. The two dikes plotted represent the least and most silicic of the six that were analyzed. (b) REE/chondrite plot for the more mafic and trachydacitic groups from the Mount Perkins magmatic system. Heavy solid lines are granodiorite from the Mount Perkins pluton; medium solid lines are trachydacite flows; thin dotted line is a diorite from the Mount Perkins pluton; thin dashed line is a trachyandesite flow. 

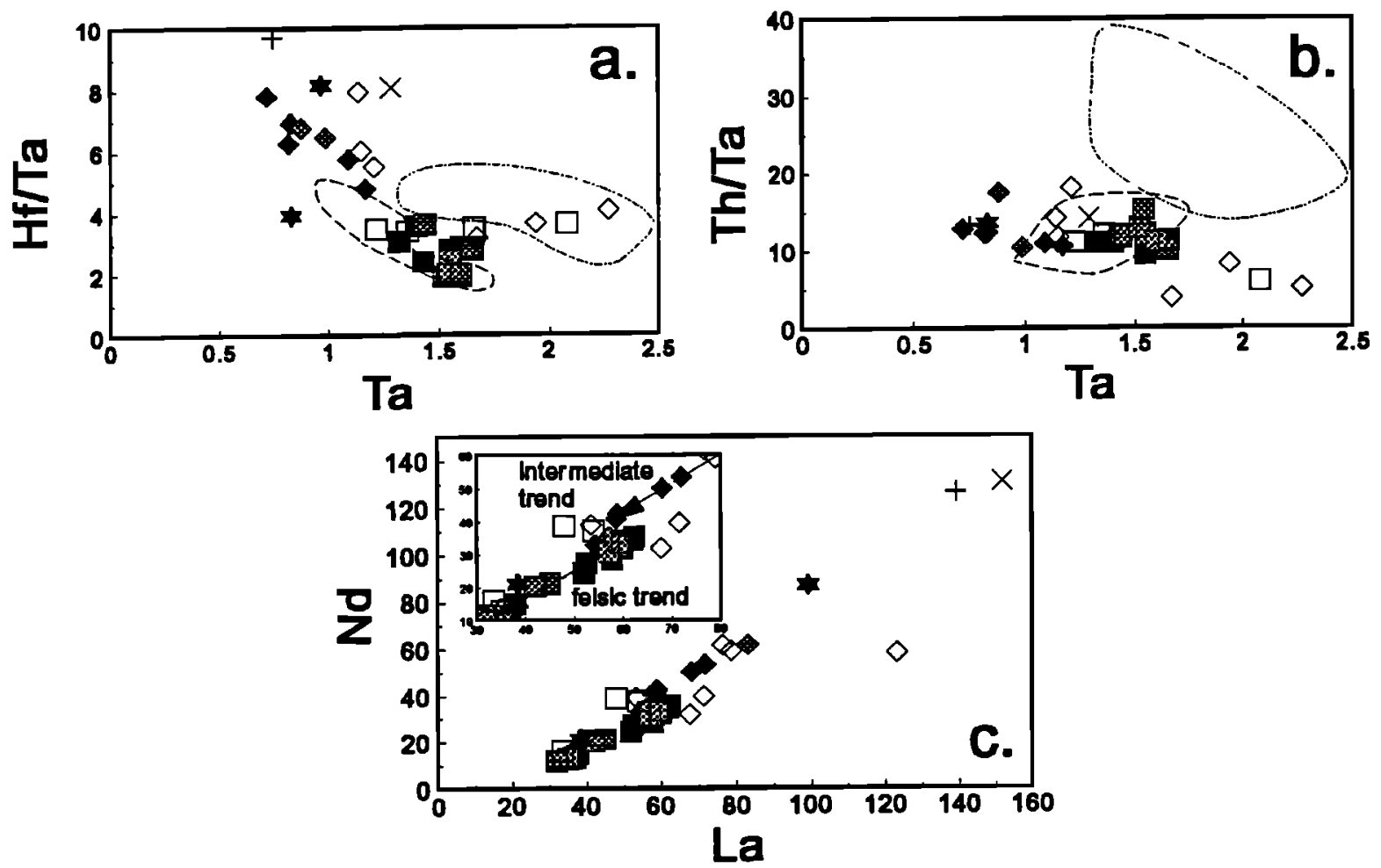

Figure 6. Volcanic and intrusive rocks within the Mount Perkins and nearby magmatic systems. (a) Hf/Ta versus Ta. Symbols are the same as for Figure 4. The area enclosed by the dashed line shows the intermediate and felsic rocks from the River Mountains-Wilson Ridge system [Smith et al., 1990]. The area enclosed by the dotted line shows the granodiorite and granite from the Aztec Wash pluton [Falkner et al., 1995]. (b) Th/Ta versus Ta. Symbols and line types are the same as in Figure 6a. (c) Nd versus La for volcanic and intrusive rocks within the Mount Perkins magmatic system showing parallel but not colinear trends for the intermediate and felsic magma groups.

Perkins magmatic system. These data are, however, consistent with the field relations and rule out potential correlations with most other magmatic systems in the region. For example, compared to the intermediate to felsic groups of the 14.5-16.0 Ma Mount Perkins system, the 15.7 Ma Aztec Wash pluton in the nearby Eldorado Mountains [Falkner et al., 1995] has similar REE patterns and isotopic compositions but noticeable differences in $\mathrm{Hf}$, Th, and Ta concentrations (Figures 6a and 6b). In contrast, subtle differences in the $\mathrm{Sr}$ and Nd isotopic compositions distinguish the 14.5-16.0 Ma Mount Perkins system from the younger 13.0-13.5 Ma Wilson Ridge-River Mountains system [Weber and Smith, 1987; Larsen and Smith, 1990; Feuerbach et al., 1993] (Figure 7a), which lies well to the north of Mount Perkins (Figure 1).

\section{Discussion}

\section{Tilted Volcanoes}

The field, geochronologic, and geochemical data together demonstrate that the Mount Perkins block exposes a cross section of a preextensional to synextensional magmatic system, including volcanic edifices, hypabyssal dike swarms, and part of the plutonic root. The most compelling evidence in support of this hypothesis is the relative proximity of the Red Gap Mine volcanics, Mount Perkins dike swarm, trachydacite domes and flows of the Dixie Queen Mine volcanics, and Mount Perkins pluton. For example, restoring the Mount Perkins block to paleohorizontal places the Red Gap Mine volcanics and trachydacite dome complex above the Mount Perkins dike swarm and pluton, respectively.
The preextensional system at Mount Perkins primarily involved the production of intermediate group magmas of the Mount Perkins pluton and Dixie Queen Mine volcanics and construction of a stratovolcano, as manifested in the trachydacite domes and trachydacite and trachyandesite flows

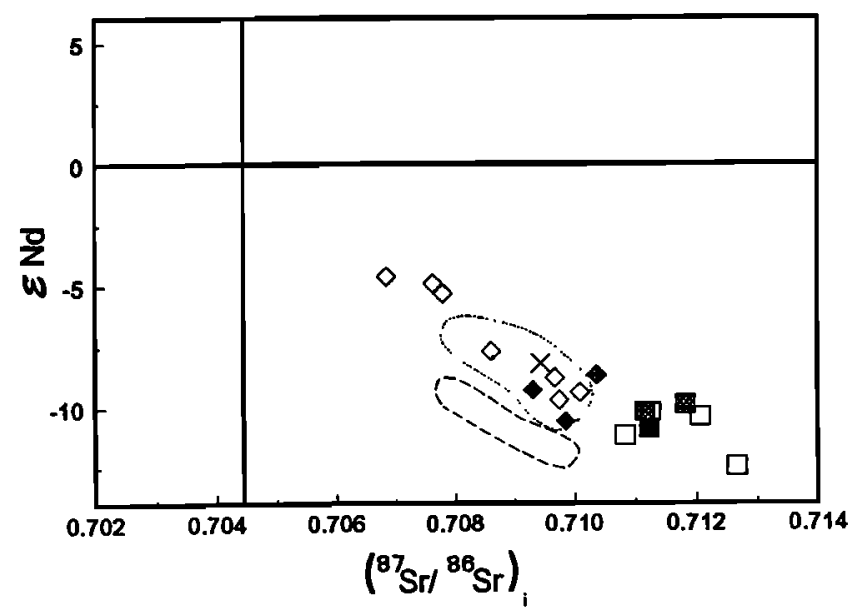

Figure 7. Nd and $\mathrm{Sr}$ isotopic compositions for volcanic and intrusive rocks of the Mount Perkins and nearby magmatic systems. Symbols are the same as for Figure 4 . The area enclosed by the dashed line represents trachydacitic and rhyolitic rocks from the River Mountains and a granodiorite from the Wilson Ridge pluton [Feuerbach et al., 1993]. The area enclosed by the dotted line shows plutonic rocks from the Aztec Wash pluton [Falkner et al., 1995]. 
of the Dixie Queen Mine volcanics. The current level of erosion intersects the upper and hypabyssal levels of the stratovolcano. Although the geochemical data indicate a genetic link between the trachydacite domes and flows and quartz diorite to hornblende granodiorite phases of the Mount Perkins pluton (Figures. 5b, 6, and 7), the pluton and trachydacite dome complex are not physically linked at exposed structural levels (Figure 2). Because the steeply dipping dikes that comprise the Mount Perkins pluton restore to a subhorizontal orientation, we conclude that the pluton was emplaced as a laccolithlike body, which emanated from a poorly exposed stock situated beneath the core of the stratovolcano (Figures $2 \mathrm{~b}$ and 8 ).

The late preextensional system at Mount Perkins produced the granodiorite-granite phase of the Mount Perkins pluton, east to northeast striking rhyolite dikes, and lowermost part of the Red Gap Mine volcanics. The granodiorite-granite phases of the pluton also restore to a subhorizontal orientation. Preextensional east-northeast striking basaltic andesite dikes feed sills just to the north of the Mount Perkins block in the central Black Mountains [Faulds, 1993a]. Similar relations may characterize the preextensional rhyolitic system at Mount Perkins but cannot be verified based on current exposures.

Synextensional magmatism generated a large rhyolite dome complex at Mount Perkins, which incorporates the bulk of the Red Gap Mine volcanics and northerly striking Mount Perkins dike swarm. The rhyolite dome complex developed directly on top of the preextensional stratovolcano. Physical and geochemical relations strongly indicate a genetic link between the Mount Perkins dike swarm and Red Gap Mine volcanics. The present erosional surface intersects the rhyolite dome complex at hypabyssal levels within the rhyolite dike swarm. Rhyolite domes have been largely eroded from the west flank of Mount Perkins but are preserved in the hanging wall of the Mockingbird Mine fault. Normal displacement on the Mockingbird Mine fault essentially decapitated the rhyolite dome complex and translated the upper part of the complex 5$6 \mathrm{~km}$ to the east of its hypabyssal roots. Such relations exemplify how tilting and the subsequent erosion of the upthrown parts of fault blocks, as well as structural dismemberment by normal faulting, can significantly obscure major volcanic centers.

The Inyo and Mono domes of east central California, which lie within the actively extending Owens Valley region [Hill et al., 1985], may represent modern-day, untilted analogs to the Miocene magmatic system at Mount Perkins. The dome-upon-dome structure of the Mono domes is similar to that of the trachydacitic and rhyolitic sequences at Mount Perkins, although the volume of the basal dacitic lavas in the Mono domes [Kelleher and Cameron, 1990] is considerably less than at Mount Perkins. In addition, both the Mono domes [Bursik and Sieh, 1989] and 11-km-long Inyo volcanic chain [Eichelberger et al., 1985, 1988; Fink, 1985; Mastin and Pollard, 1988; Suemnicht and Varga, 1988] were fed by dikes similar in length to those within the Mount Perkins dike swarm.

\section{Interplay Between Magmatism and Extension}

The rhyolitic magmatism at Mount Perkins began immediately prior to the onset of regional east-west extension, as evidenced by the widely spaced east to northeast striking rhyolite dikes and concordant tilts in the lowermost part of the Red
Gap Mine volcanics. It blossomed during and immediately after the onset of extension (15.7 to $14.5 \mathrm{Ma}$ ) with the emplacement of the massive northerly striking, Mount Perkins dike swarm and deposition of the bulk of the Red Gap Mine volcanics. The rhyolitic magmatism at Mount Perkins shut down, however, by $-14.5 \mathrm{Ma}$, essentially during peak extension.

Emplacement modes of magmas within the Mount Perkins magmatic system changed during the onset of regional extension. Prior to extension, intrusions were emplaced as subhorizontal dikes with relatively low aspect ratios, east to northeast striking steeply dipping dikes, and stocks. Some of the subhorizontal intrusions were probably laccolithlike bodies associated with stocks. Similar preextensional east to northeast striking dikes, subhorizontal intrusions, and stocks have been observed in other parts of the northern Colorado River extensional corridor, including the Oatman mining district in the southern Black Mountains [Thorson, 1971; DeWitt et al., 1986], northern Eldorado Mountains [Anderson, 1971], and central Black Mountains directly north of the Mount Perkins block [Faulds, 1993a]. Best and Christiansen [1991] suggested that within the Great Basin, large volumes of magma were emplaced as subhorizontal sheets during peak Tertiary volcanism, which coincided with a period of little regional extension. A large, present-day subhorizontal intrusion may also underlie part of the Rio Grande rift [Rinehart et al., 1979]. In contrast, synextensional intrusions at Mount Perkins and elsewhere in the extensional corridor [e.g., Nakata, 1982; Anderson, 1993; Falkner et al., 1995] are characterized by large northnorthwest striking sheeted dike complexes with high aspect ratios.

The changes in emplacement modes at the onset of extension reflect a major reorganization of the regional stress field. The preextensional intrusions indicate a nearly isotropic regional stress field that may have experienced periodic permutations. The subhorizontal intrusions were probably emplaced during periods when the least principal stress had a subvertical orientation, whereas east to northeast striking dikes probably reflect a subhorizontal, north to northwest trending orientation of the least principal stress. The latter orientation may imply small amounts of north-south extension in the Mount Perkins region prior to $-15.7 \mathrm{Ma}$. Synvolcanic north-south extension has also been noted in the northern Basin and Range province [Best, 1988; Bartley, 1990]. In the Mount Perkins region, however, north-south extension ceased at $\sim 15.7 \mathrm{Ma}$, significantly before volcanism terminated at $\sim 11 \mathrm{Ma}$. Although difficult to quantify based on available data, the volume of subhorizontal intrusions in the northern part of the extensional corridor appears to be roughly comparable to that of the east to northeast striking dikes, which suggests that vertical inflation of the crust may have been as great as north-south extension. Some permutations in the regional stress field may have been magmatically induced, as emplacement of dikes can locally overwhelm the regional stress field leading to shifts in the least principal stress direction [e.g., Parsons and Thompson, 1991]. Significant permutations in the regional stress field of probable magmatic origin have been documented for relatively brief time intervals elsewhere in the Basin and Range province [Minor, 1995]. It is noteworthy that even during the inferred period of little differential stress, magmas 


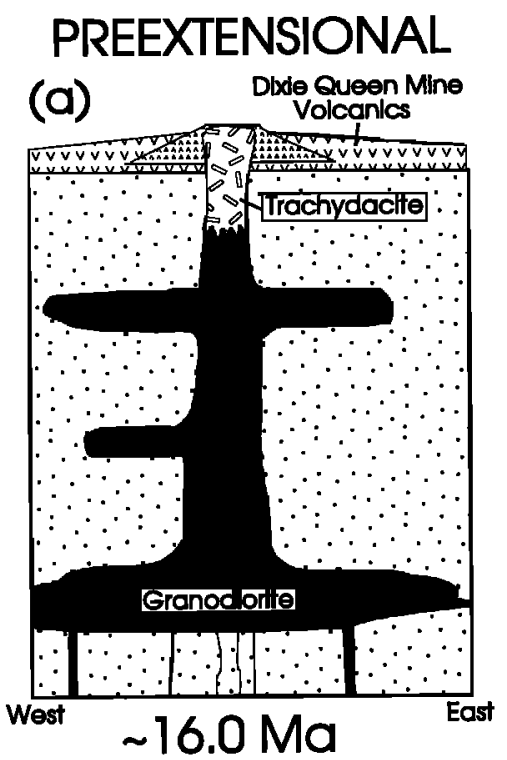

SYNEXTENSIONAL

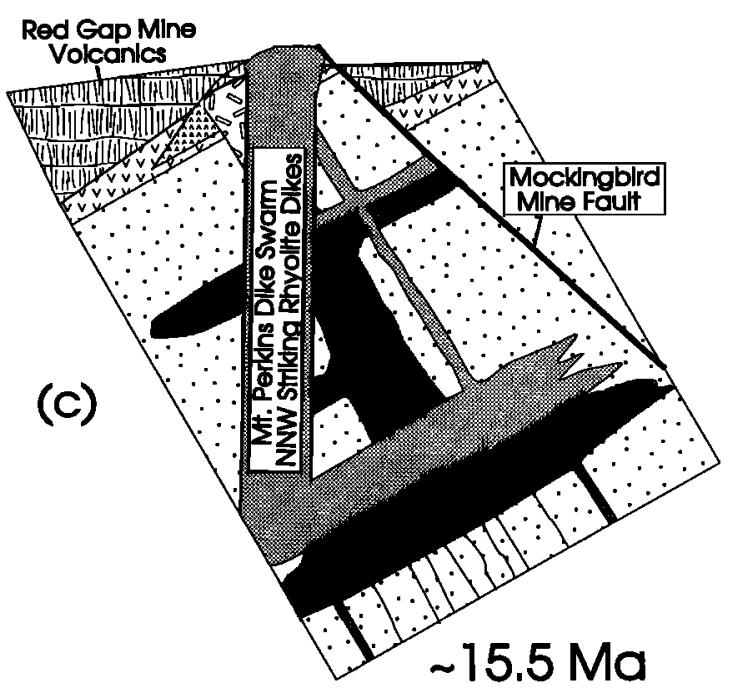

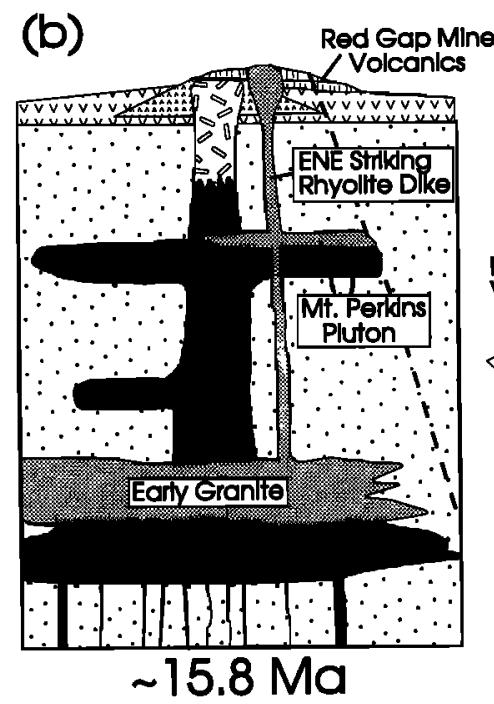

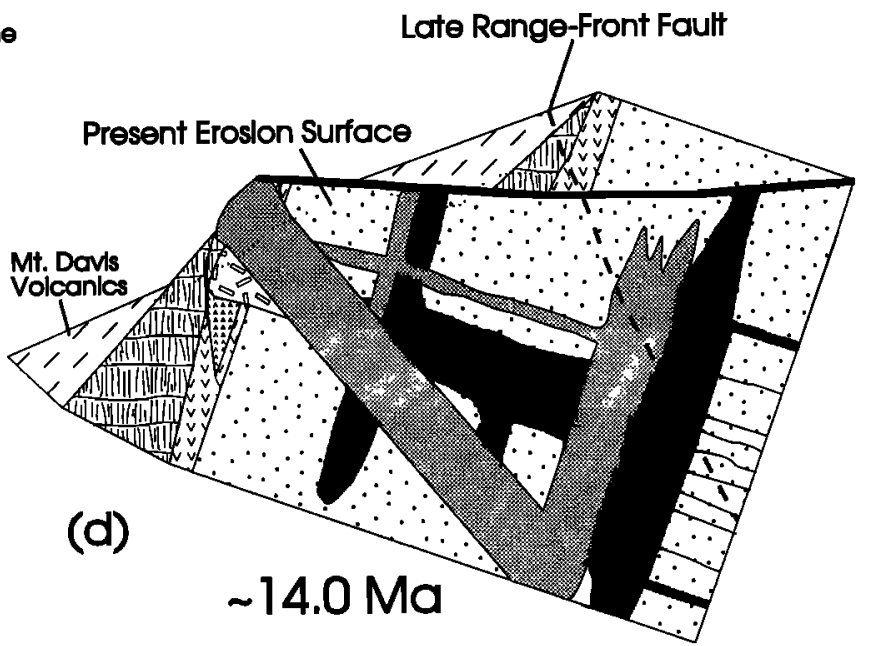

Figure 8. Schematic model of the evolving magmatic system at Mount Perkins. (a) Preextensional system at $\sim 16.0 \mathrm{Ma}$; regional stress field is nearly isotropic. A trachydacitic stratovolcano is situated above a granodiorite stock and attendant laccoliths. Magmas are mostly trapped as subhorizontal intrusions, which generate significant crustal heating and melting and prevent basaltic melts from reaching the surface. (b) Immediately prior to the onset of extension at $\sim 15.8 \mathrm{Ma}$; regional stress field is nearly isotropic. Rhyolitic magmatism supersedes trachydacitic magmatism and produces east to northeast striking dikes and domes, as the level of crustal melting shallows and/or the contribution of upper crustal melt increases. (c) Synextensional system $\sim 15.5 \mathrm{Ma}$; regional stress field is decidedly anisotropic with an east-west trending, subhorizontal least principal stress. Rhyolitic magmatism continues with the emplacement of a large, northerly striking dike swarm and associated rhyolite domes, which are largely superimposed on the older stratovolcano. Abundant dilational fractures and normal faults allow highly viscous rhyolitic melts to reach the surface. Crustal heating and melting slows as residence time of melts within the crust decreases. Silicic magma chambers are eventually evacuated or quenched leading to an abrupt termination in rhyolitic magmatism during peak extension ( $14.5 \mathrm{Ma})$. (d) Synextensional mafic magmatism $\sim 14.0 \mathrm{Ma}$; stress field is anisotropic. Mafic magmas derived largely from the mantle lithosphere have ready access to the surface. The thermal anomaly beneath Mount Perkins has died out.

were not emplaced along preexisting anisotropies (e.g., foliation in Proterozoic gneisses), at least not at exposed structural levels. Once major east-west extension began at 15.7 Ma, magmas were emplaced as subvertical northerly striking, sheeted-dike complexes oriented perpendicular to the easterly trending least principal stress. Such large sheetlike bodies are compatible with established emplacement modes for extensional settings [e.g., Paterson and Fowler, 1993].

Although the relative timing of magmatism and extension at Mount Perkins is compatible with extension being driven by uplift, doming, and subsequent gravity gliding above shallowly emplaced plutons [e.g., Rowley et al., 1989], 
regional relations suggest that such a process did not play a major role. For example, the Mount Perkins block lies within the $30,000 \mathrm{~km}^{2}$ Colorado River extensional corridor and is part of a $5000 \mathrm{~km}^{2}$ region that underwent large magnitude extension between 15.7 and $11.3 \mathrm{Ma}$. It is not an anomalous, highly extended block, as might be expected in a gravity glide model. Moreover, large magnitude extension within the corridor is not confined to individual magmatic centers nor to the east-west trending magmatic belts of Smith and Faulds [1994]. Some of the more highly extended parts of the corridor have actually experienced relatively little magmatism [e.g., Fryxell et al., 1992], whereas some of the least extended regions, in terms of mechanical extension, tend to be loci for magmatism [Faulds et al., 1994b]. These relations suggest that most of the extension at Mount Perkins was not induced by local uplift and gravity gliding above shallow intrusions but was instead part of a regional event influenced primarily by the configuration of the regional stress field.

The change in the stress field at the onset of extension occurred after magma compositions had changed from dominantly trachydacitic to rhyolitic. The onset of tilt fanning within the Red Gap Mine volcanics demonstrates that rhyolites were erupted before, during, and after the onset of extension. Thus, although the spatial and temporal relationships between the intermediate and felsic groups indicate that both groups are manifestations of the same thermal anomaly and possibly utilized the same magma chamber, the evolution of the magmatic system to progressively more silicic compositions was at least partly independent of the style of deformation in the upper crust.

Many of the trends observed between REE and high field strength elements are parallel and roughly colinear (Figure 6), which indicates that the intermediate and felsic groups evolved from similar sources and by similar processes. However, the significant depletion in $\mathrm{Nd}$ and enrichment in La of the least evolved rhyolite with respect to the most evolved trachydacite (Figure 6c) cannot be explained by any reasonable closed or open system fractionation model. Thus the two groups probably are not linked by fractionation along one liquid line of descent. The parental magmas for the two groups either were generated from slightly different sources or were fractionated along slightly different paths at depth. The higher $\mathrm{Sr}$ isotopic compositions of the felsic group relative to the intermediate group (Figure 7) suggest the former, which may indicate that continental crust was more involved in the genesis of the felsic group. Major and trace element variations within both groups suggest that they differentiated largely by crystal fractionation of the observed phases including such accessory minerals as sphene, apatite, zircon, and chevkinite [Feuerbach et al., 1994]. However, the withingroup variations in $\mathrm{Sr}$ and $\mathrm{Nd}$ isotopic compositions indicate that assimilation of continental crust or inmixing of melts of continental crust also contributed to the differentiation.

The high-Sr and low-Nd isotopic compositions of the intermediate and felsic magmas suggest that their genesis involved a significant component of upper crust. Furthermore, the radiogenic $\mathrm{Sr}$ isotopic compositions are greatest in the felsic group, which indicates a corresponding increase in the contribution of upper crustal melt. The eruption rate of rhyolitic magmas increased significantly immediately after the onset of extension before diminishing abruptly at peak extension when mafic magmas began erupting. Thus as extension accelerated, upper crustal melts were evacuated and/or generated at an increasingly rapid pace just prior to being completely expended from the magmatic system.

A model similar to that proposed by Best and Christiansen [1991] may be applicable to the Mount Perkins magmatic system. Prior to extension, large volumes of mafic magma derived from the mantle lithosphere may have been trapped as subhorizontal sheets within the crust, which promoted crystallization of the basalt, as well as extensive and rapid crustal melting [Huppert and Sparks, 1988]. The magma probably ponded at levels within the crust where it was neutrally buoyant. Early in the evolution of the Mount Perkins system, the mafic magma ponded at relatively deep levels because of the felsic nature of the crust [Glazner and Ussler, 1989]. Mixing of the crustal melts with the differentiating basaltic magmas then produced low-silica end members of the intermediate group [see Gans et al., 1989]. Subsequent batches of mafic magma were blocked by the developing subhorizontal intrusions of intermediate magma, which led to further heating and melting of the crust as well as crystallization of the intermediate magmas. Further inmixing of crustal melt and crystallization of the more mafic melts produced the more silicic, intermediate group magmas (e.g., trachydacites). The lower density of the silicic intermediate magmas promoted their ascent to relatively shallow crustal levels. The ascent of the intermediate magmas may have removed density barriers to basalts and thus permitted their rise to shallower levels. Subsequent ponding of the basalts at shallower crustal levels and the resultant heating and crustal melting may have generated the felsic group of magmas. The preextensional Mount Perkins system had probably evolved to this point, as evidenced by the copious amounts of preextensional intermediate magmas and lesser rhyolites.

Although the Mount Perkins system may have eventually evolved into a large rhyolitic center without major extension, full-blown regional extension facilitated the venting of the highly viscous rhyolitic magmas by creating abundant dilational fractures and faults, which served as channelways for intrusion. Once major extension began and the rhyolitic magmas were evacuated, mafic magmas were no longer trapped as subhorizontal sheets within the crust and thus crustal melting was minimized. This may explain why rhyolitic magmatism at Mount Perkins ended abruptly during peak extension and gave way to mafic magmatism. The quantity of rhyolitic magma available to the system was probably finite so long as major extension continued and mafic magmas had ready access to the surface through abundant channelways. Major extension served to flush out preexisting crustal melts and hybrid magmas by generating abundant pathways to the surface. Any remaining crustal melts were probably largely quenched through rapid cooling induced by tectonic denudation. Thick sequences of 15.212.8 Ma basalt flows within the synextensional Mount Davis volcanics (Figures 2 and 3), with little if any intercalated rhyolite, attest both to the presence of large volumes of mafic magma and ease of access of these magmas to the surface. Mafic magmatism in the Mount Perkins region ended $\sim 11 \mathrm{Ma}$ coincidental with the cessation of extension.

Extension and magmatism may have also interacted in more subtle ways at Mount Perkins. For example, injection of the dike swarm and increased pore pressure associated with the magmatic system may have facilitated slip along the Mockingbird Mine fault and controlled the location of the 
maximum displacement. Alternatively, greater tectonic denudation and associated pressure reduction may have focused venting of the synextensional rhyolitic system within the footwall of the Mockingbird Mine fault in the area of maximum displacement. It is noteworthy that the Mount Perkins structural block terminates or loses definition alongstrike to the north and south only a short distance from the lateral terminations of the magmatic system.

Initiation of magmatism clearly preceded the onset of extension within the northern Colorado River extensional conridor. Magmatism may have indeed promoted extension through thermal weakening of the crust, increased pore pressure, and dike emplacement at depth [e.g., Gans et al., 1989; Meyer and Foland, 1991]. In addition, thickening of the crust through the inflationary effects of subhorizontal intrusions may have been significant enough to partially drive extension [e.g., Hill et al., 1992]. Quantification of these processes is difficult, however, even at Mount Perkins, where the upper several kilometers of an individual magmatic system have been exposed in cross section.

The evolution of the Mount Perkins magmatic system does illustrate that the onset of major regional extension and accompanying development of large differential stresses can have a demonstrable impact on the emplacement modes of magmas within the upper crust by rapidly inducing injection into large, subvertical sheeted dike complexes oriented perpendicular to the least principal stress. This may, in turn, facilitate "crustal flushing" and "quenching" of existing magmatic systems. It also appears that preextensional magmatic systems may partly control the segmentation of the upper crust during extension, particularly its partitioning into large structural blocks.

\section{Appendix: Analytical Techniques}

\section{The ${ }^{40} \mathrm{Ar} /{ }^{39}$ Ar Geochronology}

Mineral separations were carried out utilizing standard techniques at the University of Iowa under the supervision of J. Faulds. Wherever possible, high-K mineral phases were extracted. However, basalt and basaltic andesite flows that lack a K-bearing phenocryst phase constitute a large part of the stratigraphic section in the Mount Perkins region. Groundmass concentrates were therefore extracted from the interior of several holocrystalline basalt and basaltic andesite flows. Such "whole rock" samples have been shown to yield excellent results in many cases [Nauert and Gans, 1994].

All ${ }^{40} \mathrm{Ar} /{ }^{39} \mathrm{Ar}$ analyses were performed at the Laboratory for Argon Geochronology at the University of California, Santa Barbara, under the supervision of P. Gans. The ${ }^{40} \mathrm{Ar} /{ }^{39} \mathrm{Ar}$ data for individual samples are available as an electronic supplement through AGU (Table A1 ${ }^{1}$ ). Irradiated samples weighing 2 to $15 \mathrm{mg}$ were step heated in a

\footnotetext{
'An electronic supplement of this material may be obtained on a diskette or Anonymous FTP from KOSMOS.AGU.ORG. (LOGIN to AGU's FTP account using ANONYMOUS as the usemame and GUEST as the password. Go to the right directory by typing CD APPEND. Type LS to see what files are available. Type GET and the name of the file to get it. Finally, type EXIT to leave the system.) (Paper number 95JB01375, The Mount Perkins block, northwestern Arizona: An exposed cross section of an evolving, preextensional to synextensional magmatic system, by J. E. Faulds et al.). Diskette may be ordered from the American Geophysical Union, 2000 Florida Avenue, N.W., Washington, DC 20009; $\$ 15.00$. Payment must accompany order.
}

Modifications Limited double vacuum-type resistance furnace for $10 \mathrm{~min}$ on each step. Extracted gas was purified with SAES-type ST-172 (Zr-V-Fe) getters and then analyzed on a Mass Analyzer Products Limited 216 mass spectrometer equipped with a Bauer Signer source and a Johnston, Multiplier. At the typical operating gain, the mass spectrometer has sensitivity of $\sim 2 \times 10^{-14} \mathrm{~mol} / \mathrm{V}$. Typical system blanks are $2 \times 10^{-16} \mathrm{~mol}{ }^{40} \mathrm{Ar}$ and $1.5 \times 10^{-18} \mathrm{~mol}{ }^{36} \mathrm{Ar}$. All samples were irradiated in the U.S. Geological Survey Triga reactor. The neutron flux was monitored using sanidine from Taylor Creek Rhyolite (85G003) with an accepted age of $27.92 \mathrm{Ma}$ [Dalrymple and Duffield, 1988]. Reactor constants for the production of interfering isotopes were not measured directly but were assigned the nominal values determined by Dalrymple et al. [1981]. Analytical data were reduced to produce spectra and isochron plots using the EyeSoreChron program developed by B. Hacker at Stanford University.

Step heating experiments (10-16 steps) were carried out on all samples to obtain higher precision ages and to evaluate whether the isotopic systematics of the samples have been affected by either alteration or xenocrystic contamination. Nearly all samples yielded easily interpretable ages. All ages are in agreement with their known stratigraphic position. Most samples yielded simple flat release spectra with a welldefined plateau over a significant part of the spectrum. However, several of the "whole rock" samples yielded humpshaped, S-shaped, or more complicated spectra and poorly defined isochrons that are more difficult to interpret. It has been determined empirically that the ages corresponding to the tops of the humps or the middle, flattish part of the Sshaped spectra from whole rock samples are the best measure of the eruptive age [Nauert and Gans, 1994; P. Gans, unpublished data, 1994]. Assignment of uncertainties to these more disturbed spectra is rather subjective, as contiguous steps are not strictly within analytical error of each other. In any case, our estimated analytical uncertainties on most samples is less than $0.05 \mathrm{Ma}$ and in the worst cases does not exceed $\sim 0.5 \mathrm{Ma}$.

\section{Geochemical Analyses}

Major and trace element analyses for 30 samples were carried out at the GeoAnalytical Laboratory at Washington State University using automated $X$-ray spectrometry and inductively coupled plasma source mass spectrometer. Procedures are described by Hooper et al. [1993] and Knaack et al. [1995].

Seven samples were analyzed for isotopic compositions at the University of Kansas. Samples were dissolved at $\sim 180^{\circ} \mathrm{C}$ in a sealed bomb using an $\mathrm{HF} / \mathrm{HNO}_{3}$ mixture. Samples were total spikes for $\mathrm{Rb}, \mathrm{Sr}, \mathrm{Nd}$, and $\mathrm{Sm}$. Separation of $\mathrm{Rb}, \mathrm{Sr}$, and REE group elements was done using standard cation exchange techniques. The HDEHP-on-Teflon method of White and Patchett [1984] was used for separation of $\mathrm{Sm}$ and $\mathrm{Nd}$. The $\mathrm{Hbr}$ and $\mathrm{HNO}_{3}$ methods were used for separation of $\mathrm{Pb}$ and $U$, respectively, on aliquots from the whole rock solution. All isotopic analyses were done on a VG Sector 54 mass spectrometer at the University of Kansas. Analysis of Sr and Nd was done in dynamic multicollector mode with ${ }^{88} \mathrm{Sr}=4 \mathrm{~V}$ and ${ }^{144} \mathrm{Nd}=1 \mathrm{~V} ; \mathrm{Rb}$ and $\mathrm{Sm}$ were analyzed in static multicollector mode with ${ }^{87} \mathrm{Rb}=200 \mathrm{mV}$ and ${ }^{147} \mathrm{Sm}=500 \mathrm{mV}$. Analyses for $\mathrm{Sr}$ and $\mathrm{Sm}$ were done on single Ta filaments; $\mathbf{R b}$ was run on single $\mathrm{Re}$ filaments. $\mathrm{Nd}$ was run both as $\mathrm{NdO}^{+}$ 
and $\mathrm{Nd}^{+}$. Analytical blanks were less than $100 \mathrm{pg}$ for all elements. $\mathrm{Sr}$ isotopic compositions are normalized for ${ }^{86} \mathrm{Sr} /{ }^{88} \mathrm{Sr}=0.1194$ and referenced to NBS-987 ${ }^{87} \mathrm{Sr} /{ }^{86} \mathrm{Sr}=0.710250$. Reproducibility of $\mathrm{Sr}$ values are better than \pm 0.000020 based on replicate runs of NBS-987. Nd isotopic compositions are normalized to ${ }^{146} \mathrm{Nd} /{ }^{144} \mathrm{Nd}=0.7219$ and referenced for LaJolla ${ }^{143} \mathrm{Nd} /{ }^{144} \mathrm{Nd}=0.511850$. Epsilon values for $\mathrm{Nd}$ at crystallization are calculated using $\left({ }^{143} \mathrm{Nd} /{ }^{144} \mathrm{Nd}\right)$ (CHUR, $\left.0 \mathrm{Ma}\right)=0.512638$ and ${ }^{147} \mathrm{Sm} /{ }^{144} \mathrm{Nd}$ (CHUR, $0 \mathrm{Ma}$ ) $=0.1967$. Reproducibility on Nd values is $\sim 0.25$ epsilon units based on replicate analyses of LaJolla and in-house standards.

Acknowledgments. This work was supported primarily by National Science Foundation grant EAR 91-20383 awarded to J. Faulds and partly by NSF grant EAR 92-06055. Isotopic analyses were funded by the Center for Volcanic and Tectonic Studies at the University of Nevada, Las Vegas. We thank James Riley and Glenn Anderson of the National Park Service at Lake Mead National Recreation Area (LMNRA) for providing boat access to isolated areas. We also thank Kent Turner and William Burke of the LMNRA for logistical support in the park. We especially appreciate the careful work of Bridget Tompkins who prepared most of the mineral separations for ${ }^{40} \mathrm{Ar} /{ }^{39} \mathrm{Ar}$ analysis. We are also grateful to James Conrad, U.S. Geological Survey, for sharing K/Ar data and sample locations, Jack Hamm of Combined Metals Reduction Company for enlightening discussions on the local geology, and David Foster of LaTrobe University for the fission-track ages on the Mount Perkins pluton. Discussions with R. E. Anderson and Eugene Smith were also helpful. Myron Best, Allen Glazner, Calvin Miller, Jane Nielson, and Steve Reynolds provided helpful reviews.

\section{References}

Anderson, R.E., Thin skin distension in Tertiary rocks of southeastern Nevada, Geol. Soc. Am. Bull., 82, 43-58, 1971.

Anderson, R.E., Large magnitude late Tertiary strike-slip faulting north of Lake Mead, Nevada, U.S. Geol. Surv. Prof. Pap., 794, 18 pp, 1973.

Anderson, R.E., Geologic map of the Boulder City 15-minute Quadrangle, Clark County, Nevada, U.S. Geol. Surv. Geol. Quad. Map, GQ-1395, 1977.

Anderson, R.E., Geologic map of the Black Canyon 15-minute Quadrangle, Mohave County, Arizona and Clark County, Nevada, U.S. Geol. Surv. Geol. Quad. Map, GQ-1394, 1978.

Anderson, R.E., Tectonic significance of a Miocene dike swarm and its post-emplacement vertical and meridional collapse, Lake Mead area, Nevada, Arizona, Geol. Soc. Am. Abstr. Programs, 25(5), 3, 1993.

Angelier, J., B. Colletta, and R.E. Anderson, Neogene paleostress changes in the Basin and Range: A case study at Hoover Dam, Nevada-Arizona, Geol. Soc. Am. Bull., 96, 347-361, 1985.

Armstrong, R.L., and P. Ward, Evolving geographic patterns of Cenozoic magmatism in the North American Cordillera: The temporal and spatial association of magmatism and metamorphic core complexes, J. Geophys. Res., 96, 13,201-13,224, 1991.

Asmerom, Y., J.K. Snow, D.K. Holm, S.B. Jacobsen, B.P. Wernicke, and D.R. Lux, Rapid uplift and crustal growth in extensional environments: An isotopic study from the Death Valley region, California, Geology, 18, 223-226, 1990.

Axen, G.J., W.J. Taylor, and J.M. Bartley, Space-time patterns and tectonic controls of Tertiary extension and magmatism in the Great Basin of the western United States, Geol. Soc. Am. Bull., 105, 56-76, 1993.

Bartley, J.M., Changing Tertiary extension directions in the Dry Lake Valley area, Nevada, and a possible dynamic model, in Compressional and Extensional Structural Styles in the Northern Basin and Range, pp. 35-39, Geological Society of Nevada, Reno, 1990.

Bartley, J.M., G.J. Axen, W.J. Taylor, and J.E. Fryxell, Cenozoic tectonics of a transect through eastern Nevada near $38 \mathrm{~N}$ latitude, in Cordilleran Section Field Trip Guidebook, edited by D. L. Weide and M. L. Faber, pp. 1-20, Geological Society of America, Boulder, Colo., 1988.
Berger, G.W., and D. York, Geothermometry from ${ }^{40} \mathrm{Ar} /{ }^{39} \mathrm{Ar}$ dating experiments, Geochim. Cosmochim. Acta, 45, 795-811, 1981.

Best, M.G., Early Miocene change in direction of least principal stress, southwestern United States: Conflicting inferences from dikes and metamorphic core-detachment fault terranes, Tectonics, 7, 249-259, 1988.

Best, M.G., and E.H. Christiansen, Limited extension during peak Tertiary volcanism, Great Basin of Nevada and Utah, J. Geophys. Res., 96, 13,509-13,528, 1991.

Bosworth, W., Off-axis volcanism in the Gregory rift, east Africa: Implications for models of continental rifting, Geology, 15, 397 $400,1987$.

Bursik, M., and $\mathrm{K}$. Sieh, Range-front faulting and volcanism in the Mono basin, eastern California, J. Geophys. Res., 94, 15,587$15,609,1989$

Conrad, J.E., R.H. Hill, and R.C. Jachens, Mineral resources of the Black Mountains North and Burns Spring wilderness study areas, Mohave County, Arizona, U.S. Geol. Surv. Bull., 1737-C, 22 pp., 1990.

Dalrymple, G.B., and W. Duffield, High-precision ${ }^{40} \mathrm{Ar} /{ }^{39} \mathrm{Ar}$ dating of Oligocene rhyolites from the Mogollon-Datil volcanic field using a continuous laser system, Geophys. Res. Lett., 15, 463-466, 1988.

Dalrymple, G.B., E.C., Alexander, M.A. Lanphere, and G.P. Kraker, Irradiation of samples for ${ }^{40} \mathrm{Ar} /{ }^{39} \mathrm{Ar}$ dating using the Geological Survey TRIGA reactor, U.S. Geol. Surv., Prof. Pap., 1176, 1981.

deVoogd, B., L. Serpa, and L. Brown, Crustal extension and magmatic processes: COCORP profiles from Death Valley and the Rio Grande rift, Geol. Soc. Am. Bull., 100, 1550-1567, 1988.

DeWitt, E., J.P. Thorson, and R.C. Smith, Geology and gold deposits of the Oatman district, northwestern Arizona, U.S. Geol. Surv. Open File Rep., 86-0638, 34 pp., 1986.

Eaton, G.P., The basin and range province: Origin and tectonic significance, Annu. Rev. Earth Planet. Sci., 10, 409-440, 1982.

Eichelberger, J.C., P.C. Lysne, C.D. Miller, and L.W. Younker, Research drilling at Inyo Domes, California: 1984 results, Eos Trans. $A G U, 66,186-187,1985$.

Eichelberger, J.C., T.A. Vogel, L.W. Younker, C.D. Miller, G.H. Heiken, and K.H. Wohletz, Structure and stratigraphy beneath a young phreatic vent: South Inyo crater, Long Valley caldera, California, J. Geophys. Res., 93, 13,208-13,220, 1988.

Elston, W.E., Overview of the Mogollon-Datil volcanic field, $N . M$. Bur. Mines Mem., 46, 43-46, 1989.

Falkner, C.M., C.F. Miller, J.L. Wooden, and M.T. Heizler, Petrogenesis and tectonic significance of the calc-alkaline, bimodal Aztec Wash pluton, Eldorado Mountains, Colorado River extensional corridor, J. Geophys. Res., 100, 10,453-476, 1995.

Faulds, J.E., Geologic map of the Black Mountains accommodation zone, Mohave County, Arizona, Contrib. Map CM-93-F, Ariz. Geol. Surv., Tucson, 1993a.

Faulds, J.E., The Mt. Perkins block, northwestern Arizona: An exposed cross section of a synextensional volcano in highly extended terrane, Geol. Soc. Am. Abstr. Programs, 25(5), 36, 1993b.

Faulds, J.E., J.W. Geissman, and C.K. Mawer, Structural development of a major extensional accommodation zone in the Basin and Range province, northwestern Arizona and southern Nevada, in Basin and Range Extensional Tectonics Near the Latitude of Las Vegas, Nevada, edited by B. Wernicke, Geol. Soc. Am., Mem. 176, 37-76, 1990.

Faulds, J.E., J.W. Geissman, and M. Shafiqullah, Implications of paleomagnetic data on Miocene extension near a major accommodation zone in the Basin and Range province, northwestern Arizona and southern Nevada, Tectonics, 11, 204$227,1992$.

Faulds, J.E., P. Gans, and E.I. Smith, Spatial and temporal patterns of extension in the northern Colorado River extensional corridor, northwestern Arizona and southern Nevada, Geol. Soc. Am. Abstr. Programs, 26(2), 51, 1994a.

Faulds, J.E., E.L. Olson, and R.L. Littrell, Magmatic origin of rupture barriers and accommodation zones in extensional orogens: Analogies between continental and oceanic rifts, Eos Trans. AGU, 75(44), Fall Meet. Suppl., 678, 1994b.

Feuerbach, D.L., E.I. Smith, J.D. Walker, and J.A. Tangeman, The role of the mantle during crustal extension: Constraints from geochemistry of volcanic rocks in the Lake Mead area, Nevada and Arizona, Geol. Soc. Am. Bull., 105, 1561-1575, 1993. 
Feuerbach, D.L, M.K. Reagan, and J.E. Faulds, Preliminary geochemical constraints on the highly tilted synextensional Mt. Perkins volcanic center in northwestern Arizona, Geol. Soc. Am. Abstr. Programs, 26(2), 51, 1994.

Fink, J.H., Geometry of silicic dikes beneath the Inyo Domes, California, J. Geophys. Res., 90, 11,127-11,133, 1985.

Frost, E.G., and D.L. Martin (Eds.), Mesozoic-Cenozoic Tectonic Evolution of the Colorado River Region, California, Arizona, and Nevada, 608 pp., Cordilleran Publishers, San Diego, Calif., 1982.

Fryxell, J.E., G. Salton, J. Selverstone, and B. Wernicke, Gold Butte crustal section, south Virgin Mountains, Nevada, Tectonics, 11, 1099-1120, 1992.

Gans, P.B., and E.L. Miller, Style of mid-Tertiary extension in eastcentral Nevada, in Geologic excursions in the overthrust belt and metamorphic core complexes of the Intermountain Region, Utah Geol. Mineral Surv., Spec. Stud. 59, Guideb. Part I, pp. 108-139, 1983.

Gans, P.B., G.A. Mahood, and E. Schermer, Synextensional magmatism in the Basin and Range province: A case study in the eastern Great Basin, Geol. Soc. Am. Spec. Pap. 233, pp. 53, 1989.

Gans, P.B., B. Landau, and P. Darvall, Ashes, ashes, all fall down: Caldera-forming eruptions and extensional collapse of the Eldorado Mountains, southern Nevada, Geol. Soc. Am. Abstr. Programs, 26(2), 53, 1994.

Glazner, A.F., and J.M. Bartley, Timing and tectonic setting of Tertiary low-angle normal faulting and associated magmatism in the southwestern United States, Tectonics, 3, 385-396, 1984.

Glazner, A.F., J.E. Nielson, K.A. Howard, and D.M. Miller, Correlation of the Peach Springs Tuff, a large-volume Miocene ignimbrite sheet in California and Arizona, Geology, 14, 840-843, 1986.

Glazner, A.F., and W. Ussler, Crustal extension, crustal density, and the evolution of Cenozoic magmatism in the Basin and Range of the western United States, J. Geophys. Res., 94, 7952-7960, 1989.

Hill, D.P., R.A. Bailey, and A.S. Ryall, Active tectonic and magmatic processes beneath Long Valley caldera, eastern California: An overview, J. Geophys. Res., 90, 11,111-11,120, 1985.

Hill, E.J., S.L. Baldwin, and G.S. Lister, Unroofing of active metamorphic core complexes in the D'Entrecasteaux Islands, Papua New Guinea, Geology, 20, 907-910, 1992.

Holm, D.K., and B. Wernicke, Black Mountains crustal section, Death Valley extended terrain, California, Geology, 18, 520-523, 1990.

Hooper, P.R., D.M. Johnson, and R.M. Conrey, Major and trace element analyses of rocks and minerals by automated $\mathrm{X}$-ray spectrometry, open file report, $36 \mathrm{pp}$., GeoAnal. Lab., Wash. State Univ., Geol. Dep., Pullman, 1993.

Howard, K.A., and B.E. John, Crustal extension along a rooted system of imbricate low-angle faults: Colorado River extensional corridor, California and Arizona, in Continental Extensional Tectonics edited by M.P. Coward, J.F. Dewey, and P.L. Hancock, Geol. Soc. London, Spec. Publ. 28, 299-311, 1987.

Huppert, H.E., and R.S.J. Sparks, The generation of granitic magmas by intrusion of basalt into continental crust, J. Petrol., 29, 599$624,1988$.

John, D.A., Tilted middle Tertiary ash-flow calderas and subjacent granitic plutons, southern Stillwater Range, Nevada: Cross sections of an Oligocene igneous center, Geol. Soc. Am. Bull., $107,180-200,1995$.

Kelleher, P.C., and K.L. Cameron, The geochemistry of the Mono Craters-Mono Lake island volcanic complex, eastern California, J. Geophys. Res., 95, 17,643-17,659, 1990.

Knaack, C., S. Cornelius, and P. Hooper, Trace element analysis of rocks and minerals by ICP-MS, open-file report, GeoAnal. Lab., Wash. State Univ., Geol. Dep., Pullman, in press, 1995.

Larsen, L.L., and E.I. Smith, Mafic enclaves in the Wilson Ridge pluton, northwestern Arizona: Implications for the generation of a calc-alkaline intermediate pluton in an extensional environment, J. Geophys. Res., 95, 17,693-17,716, 1990.

LeBas, M.J., R.W. LeMaitre, A. Streckheisen, and B. Zanettin, A chemical classification of volcanic rocks based on total alkalisilica diagrams, J. Petrol., 27, 745-750, 1986.

Lipman, P.W., The roots of ash flow calderas in western North America: Windows into the tops of granitic batholiths, $J$. Geophys. Res., 89, 8801-8841, 1984

Lister, G.S., and S.L. Baldwin, Plutonism and the origin of metamorphic core complexes, Geology, 21, 607-610, 1993.
Longwell, C.R., Reconnaissance geology between Lake Mead and Davis Dam Arizona-Nevada, U.S. Geol. Surv. Prof. Pap., 374-E, 51 pp., 1963.

Mastin, L.G., and D.D. Pollard, Surface deformation and shallow dike intrusion processes at Inyo craters, Long Valley, California, J. Geophys. Res., 93, 13,221-13,235, 1988.

Metcalf, R.V., E.I. Smith, M.W. Martin, D.A. Gonzales, and J.D. Walker, Isotopic evidence of source variations in commingled magma systems: Colorado River extensional corridor, Arizona and Nevada, Geol. Soc. Am. Abstr. Programs, 25(5), 120, 1993.

Metcalf, R.V., E.I. Smith, R.C. Reed, J.D. Walker, and D.A. Gonzales, Isotopic disequilibrium among comingled hybrid magmas: Evidence for a two-stage magma mixing-comingling process, Mt. Perkins pluton, Arizona, J. Geol., in press, 1995.

Meyer, J., and K.A. Foland, Magmatic-tectonic interaction during early Rio Grande rift extension at Questa, New Mexico, Geol. Soc. Am. Bull., 103, 993-1006, 1991.

Minor, S.A., Superposed local and regional paleostresses: Fault-slip analysis of Neogene extensional faulting near coeval caldera complexes, Yucca Flat, Nevada, J. Geophys. Res., 100, 10,507-10,528, 1995.

Nakata, J.K., Preliminary report on diking events in the Mohave Mountains, Arizona, in Mesozoic-Cenozoic Tectonic Evolution of the Colorado River Region, California, Arizona, and Nevada, edited by E.G. Frost, and D.L. Martin, pp. 85-90, Cordilleran Publishers, San Diego, Calif., 1982.

Nauert, J.L., and P.B. Gans, ${ }^{40} \mathrm{Ar} /{ }^{39} \mathrm{Ar}$ geochronology of whole-rock basalts: Examples from the Patsy Mine and Mt. Davis Volcanics, Eldorado Mountains, southern Nevada, Geol. Soc. Am. Abstr. Programs, 26(2), 76, 1994.

Nielson, J.E., D.R. Lux, G.B. Dalrymple, and A.F. Glazner, Age of the Peach Springs Tuff, southeastern California and western Arizona, J. Geophys. Res., 95, 571-580, 1990.

Parsons, T., and G.A. Thompson, The role of magma overpressure in suppressing earthquakes and topography: World-wide examples, Science, 253, 1399-1402, 1991.

Paterson, S.R., and T.K. Fowler Jr., Extensional pluton-emplacement models: Do they work for large plutonic complexes, Geology, 21, 781-784, 1993.

Petit, J.P., Criteria for the sense of movement on fault surfaces in brittle rocks, J. Struct. Geol., 9, 597-608, 1987.

Proffett, J.M., Jr., Cenozoic geology of the Yerington district, Nevada, and implications for the nature and origin of Basin and Range faulting, Geol. Soc. Am. Bull., 88, 247-266, 1977.

Rinehart, E.F., A.R. Sanford, and R.M. Ward, Geographic extent and shape of an extensive magma body at midcrustal depths in the Rio Grande rift near Socorro, New Mexico, in Rio Grande Rift: Tectonics and Magmatism, edited by R.E. Riecker, pp. 237-251, AGU, Washington, D.C., 1979.

Rowley, P.D., E.H. McKee, and H.R. Blank Jr., Miocene gravity glides resulting from the emplacement of the Iron Mountain pluton, southern Iron Springs mining district, Iron County, Utah, Eos Trans. AGU, 70, 1309, 1989.

Schmidt, M.W., Amphibole composition in tonalite as a function of pressure: An experimental calibration of the Al-in-hornblende barometer, Contrib. Mineral Petrol., 110, 304-310, 1992.

Sherrod, D., and J.E. Nielson (Eds.), Tertiary stratigraphy of highly extended terranes, California, Arizona, and Nevada, U.S. Geol. Surv. Bull., 2053, 1993.

Smith, E.I., and J.E. Faulds, Patterns of Miocene magmatism in the northern Colorado River extensional corridor, Nevada, Arizona, and California: Geol. Soc. Am. Abstr. Programs, 26(2), 93, 1994.

Smith, E.I., D.L. Feuerbach, T.R. Naumann, and J. Mills, MidMiocene volcanic and plutonic rocks of the Lake Mead area of Nevada and Arizona: Production of intermediate igneous rocks in an extensional environment, in The Nature of Cordilleran Magmatism, edited by J.L. Anderson, Geol. Soc. Am., Mem. 174, 169-193, 1990.

Smith, E. I., S.A. Morikawa, M.W. Martin, D.A. Gonzales, and J.D. Walker, Tuff of Bridge Spring: A mid-Miocene ash-flow tuff, northern Colorado River extensional corridor, Nevada and Arizona, Geol. Soc. Am. Abstr. Programs, 25(5), 148, 1993.

Suemnicht, G.A., and R.J. Varga, Basement structure and implications for hydrothermal circulation patterns in the western moat of Long Valley caldera, California, J. Geophys. Res., 93, 13,191-13,207, 1988.

Taylor, W.J., J.M. Bartley, D.R. Lux, and G.J. Axen, Timing of Tertiary extension in the Railroad Valley-Pioche transect, Nevada: 
Constraints from ${ }^{40} \mathrm{Ar} /{ }^{39} \mathrm{Ar}$ ages of volcanic rocks, J. Geophys. Res., 94, 7757-7774, 1989.

Taylor, W.J., and J.M. Bartley, Prevolcanic extensional Seaman breakaway fault and its geologic implications for eastern Nevada and western Utah, Geol. Soc. Am. Bull., 104, 255-266, 1992.

Thorson, J.P., Ignteous petrology of the Oatman district, Mojave County, Arizona, Ph.D. thesis, 189 pp., Univ. of Calif., Santa Barbara, 1971.

Weber, M.E., and E.I. Smith, Structural and geochemical constraints on the reassembly of disrupted mid-Miocene volcanoes in the Lake Mead-Eldorado Valley area of southern Nevada, Geology, 15, 553-556, 1987.

Wernicke, B., Uniform-sense normal simple shear of the continental lithosphere, Can. J. Earth Sci., 22, 108-125, 1985.

White, W.M., and J. Patchett, Hf-Nd-Sr isotopes and incompatible element abundances in island arcs: Implications for magma origins and crust-mantle evolution, Earth Planet. Sci. Lett., 67, $167-185,1984$.
J. E. Faulds, D. L. Feuerbach, and M. K. Reagan, Department of Geology, University of Iowa, Iowa City, IA 52242. (email: jfaulds@vaxa.weeg.uiowa.edu)

P. Gans, Department. of Geological Sciences, University of California, Santa Barbara, CA 93106.

R. V. Metcalf, Department of Geoscience, University of Nevada, Las Vegas, NV 89154.

J. D. Walker, Department of Geology, University of Kansas, Lawrence, KS 66045.

(Received November 18, 1994; revised April 27, 1995; accepted May 2, 1995.) 